Research Paper

\title{
Subchronic arsenism-induced oxidative stress and inflammation contribute to apoptosis through mitochondrial and death receptor dependent pathways in chicken immune organs
}

\author{
Hongjing Zhao ${ }^{1, *}$, Ying $\mathrm{He}^{1, *}$, Siwen $\mathrm{Li}^{1}$, Xiao Sun ${ }^{1}$, Yu Wang ${ }^{1}$, Yizhi Shao ${ }^{1}$, Zhijun \\ Hou $^{1}$ and Mingwei Xing ${ }^{1}$ \\ ${ }^{1}$ Department of Physiology, College of Wildlife Resources, Northeast Forestry University, Harbin 150040, Heilongjiang, \\ PR China \\ *These authors contributed equally to this work
}

Correspondence to: Mingwei Xing, email: xingmingwei@nefu.edu.cn Zhijun Hou, email: houzhijundz@hotmail.com

Keywords: arsenic, apoptosis, oxidative stress, inflammation, chicken

Received: February 01, $2017 \quad$ Accepted: March 29, $2017 \quad$ Published: April 08, 2017

Copyright: Zhao et al. This is an open-access article distributed under the terms of the Creative Commons Attribution License 3.0 (CC BY 3.0 ), which permits unrestricted use, distribution, and reproduction in any medium, provided the original author and source are credited.

\section{ABSTRACT}

In many organ dysfunctions, arsenic and its compounds are well known to induce apoptosis by the mitochondria and death receptor apoptotic pathways in liver and airway. However, it is less reported that which signaling pathways contribute to excessive apoptosis of chicken immune organs, a major target of toxic metals biotransformation, which suffer from subchronic arsenism. In this study, we investigated whether the mitochondria or death receptor apoptotic pathways activated in the immune organs (spleen, thymus and bursa of Fabricius) of one-dayold male Hy-line chickens exposed to arsenic trioxide $\left(\mathrm{As}_{2} \mathrm{O}_{3}\right)$, which were fed on diets supplemented with $0,0.625,1.25$ and $2.5 \mathrm{mg} / \mathrm{kg} \mathrm{BW}$ of $\mathrm{As}_{2} \mathrm{O}_{3}$ for 30,60 and 90 days. We found that (1) Oxidative damage and inflammatory response were confirmed in the immune organs of chickens fed on $\mathrm{As}_{2} \mathrm{O}_{3}$ diet. (2) Subchronic arsenism induced typical apoptotic changes in ultrastructure. (3) TdT-mediated dUTP Nick-End Labeling (TUNEL) showed that the number of apoptotic cells significantly increased under subchronic arsenism. (4) $\mathrm{As}_{2} \mathrm{O}_{3}$-induced apoptosis of immune organs involved in mitochondrial pathway (decrease of B-cell lymphoma-2 (Bcl-2) and increase of protein 53 (p53), Bcl-2 Associated X Protein (Bax), caspase-9, caspase-3) and death receptor pathway (increase of factor associated suicide (Fas) and caspase-8). In conclusion, this work is the first to demonstrate that the activation of mitochondria and death receptor apoptosis pathways can lead to excessive apoptosis in immune organs of chickens, which suffer from subchronic arsenism, meanwhile, oxidative stress as well as subsequent inflammatory is a crucial driver of apoptosis.

\section{INTRODUCTION}

In nature, arsenic is found among oxides and sulphur compounds, and mainly distributed through the environment by water cycling. Arsenic trioxide $\left(\mathrm{As}_{2} \mathrm{O}_{3}\right)$ has recently been recognized as one of the most effective drugs for the treatment of acute promyelocytic leukemia. Every coin has two sides, a variety of studies indicated that inorganic arsenic and its methylated metabolites have paradoxical effects, namely, anticancer and carcinogenic effects [1]. Furthermore, epidemiological studies have shown that long term exposure to arsenic can increase the risk of cancers of lung, skin or bladder in man [2]. The Environmental Protection Agency and World Health Organization, in spite of that, have lowered the acceptable limit of arsenic in drinking water to $10 \mathrm{ppb}$, the concurrence of inorganic arsenic in groundwater has been reported in many Latin America and Asia countries, where inorganic arsenic concentration is up to $5300 \mathrm{ppb}[3,4]$. For one thing, Gaworecki et al. [5] have reported that $25 \mathrm{ppm}$ arsenicexposed killifish during embryogenesis could initiate molecular changes that appeared to lead to aberrant muscle 
formation. For another in rats, $\mathrm{As}_{2} \mathrm{O}_{3}$ at a level of $5 \mathrm{mg}$ / $\mathrm{kg}$ body weight (BW)/day elevated the levels of caspase-3 and nitric oxide and increased the expression of nucleic factor $\kappa \mathrm{B}(\mathrm{NF}-\kappa \mathrm{B}) \mathrm{p} 65$ in the liver [6], which indicated the symptom of intoxication. Moreover, it has been also proved that longtime exposure to arsenic is deleterious to the liver [7], lung epithelial transformed cells [8], skin [9] and arsenic alters multiple cellular pathways, which include expression of cytokines, promotion and resistance of apoptosis and increasing oxidative stress [10], these alterations lead to disease manifestations. Recently, our studies have shown that subchronic exposure to $\mathrm{As}_{2} \mathrm{O}_{3}$ in excess of $0.625 \mathrm{mg} / \mathrm{kg}$ $\mathrm{BW}$ causes inflammation, oxidative stress and heat shock response in the liver [11], brain [12] and immune organs [13]. More and more serious conditions in arseniccontaminated water and mining activities lead to the excessive arsenic accumulation through the food chains [14], human beings are exposed to arsenic species through their diets, therefore, they are susceptible to arsenic toxicity. Based on the abovementioned reports, arsenic and arsenic compounds toxic effects on health of animals and human beings, as well as their contamination in food and water have been a big problem in the environmental safety and public health.

Oxygen is the basis of creature life. However, metabolic imbalance and overproduced free radicals (including reactive oxygen species (ROS) and $\mathrm{OH}$ ) result in severe trauma and in contribution with several other environmental or genetic factors. $\mathrm{As}_{2} \mathrm{O}_{3}$ interacts with intracellular ROS causes cell damage [15], such as breaking the balance between oxidation and anti-oxidation, thus is responsible for not only for the increase of lipid peroxidation, but also for the reduction of antioxidant glutathione (GSH) levels, and the ability to resist $\mathrm{OH}$ and inhibition of many anti-oxidative enzyme activities, such as glutathione peroxidase (GSH-Px), superoxide dismutase (SOD) and catalase (CAT) activities [16, 17]. In addition, ROS or oxidative damage has been implicated in the induction of apoptosis in the cecal tonsil of broilers exposed to nickel chloride [18]. Moreover, Yao et al. reported that cell apoptosis concurred with decreased antioxidant defense (GSH-Px activities) and increased lipid peroxidation (malondialdehyde (MDA) contents) in long-term seleniumdeficient chicken muscles [19]. Another research in chicken liver suffering from aflatoxin $\mathrm{B}_{1}$ showed that oxidative stress triggered apoptosis via the activation of both mitochondrial and death receptor apoptotic pathways [20]. Further, arsenic (+3) can significantly increase ROS generation [21] and facilitate the major apoptotic signaling events: collapse of mitochondrial membrane potential, release of cytochrome c, down-regulation of anti-apoptotic protein Bcl-2 and subsequent activation of caspase-9 and caspase-3 [22]. In chicken hearts, subchronic arsenism-induced oxidative stress is also suspected to initiate inflammation, and ROS overproduction is thought to activate NF- $\kappa$ B pathway, which leads to increased expression of pro-inflammatory mediators such as tumor necrosis factor- $\alpha$ (TNF- $\alpha)$, prostaglandin E synthase (PTGEs), cyclooxygenase-2 (COX-2), inducible nitric oxide synthase (iNOS) [23]. In Caco-2 cells, chronic arsenic $(+3)$ toxicity induces increases in the expression and release of the proinflammatory cytokines interleukin (IL)-6 and IL-8 [24], whose release depends on ROS production [25]. Lee et al. [26] demonstrated that iNOS is synthesized during inflammation and that iNOS supports nitric oxide production. Increased iNOS-mediated nitric oxide concentrations may lead to DNA damage and apoptosis. What's more, Yu et al. discovered that arsenic concentrations higher than $1 \mathrm{mM}$ induced TNF- $\alpha$ release from mononuclear cells and caused apoptosis effect on $\mathrm{T}$ cells though TNF receptor I signaling pathway [27]. Overall, increased oxidative stress and subsequent inflammation may lead to increase in apoptosis [28].

In poultry, spleen, thymus and bursa of Fabricius (BF) are primary lymphoid organs responsible for the establishment and maintenance of the lymphocyte compartment, which is irreplaceable in maintaining organism in a favourable environment. Cui et al. reported that dietary $\mathrm{NiCl}_{2}$ in excess of $300 \mathrm{mg} / \mathrm{kg}$ impaired the innate and adaptive immunity in spleen, inhibited thymocyte and $\mathrm{BF}$ growth by arresting cell cycle, increasing apoptosis, and down-regulating cytokine expression levels [29-31]. A growing body of in vitro and in vivo evidence suggests that chicken immune organs are the target organ of heavy metals exposure, such as manganese [32], zinc [33] and so on.

Apoptosis, or programmed cell death, is an important way to maintain the cellular homeostasis between cell division and cell death. It is well known that apoptosis can be triggered via two principal signaling pathways: mitochondria apoptosis pathway and death receptor apoptosis pathway. However, there have been less reports focused on the apoptosis effects of $\mathrm{As}_{2} \mathrm{O}_{3}$ on immune organs in avian species at present. In this study, we demonstrated these two pathways could be triggered in the immune organs of chickens fed with $\mathrm{As}_{2} \mathrm{O}_{3}$ diet. Decreased antioxidant capacity and increased inflammation response suggested that oxidative stress and immune injury might be an important driver of excessive apoptosis of immune organs. Our research also found that the mitochondria and death receptor pathways were involved in $\mathrm{As}_{2} \mathrm{O}_{3}$-induced apoptosis of spleen and thymus, while only the former pathway was activated in BF cells, its exact mechanism needs further study. Overall, this study provides new and comprehensive evidences for further studying the effect mechanism of $\mathrm{As}_{2} \mathrm{O}_{3}$ on chicken.

\section{RESULTS}

\section{Activities of antioxidant enzymes, GSH, $\mathrm{OH} \cdot$ and MDA content in immune organs}

Antioxidant enzyme activities, GSH, ability to resist $\mathrm{OH}$. and $\mathrm{MDA}$ content in immune organs of 
chicken treated with $\mathrm{As}_{2} \mathrm{O}_{3}$ for 30, 60 and 90 days have been shown in Figures 1 and 2. Activities of CAT, GSH, $\mathrm{GSH}-\mathrm{Px}$, and ability to resist $\mathrm{OH}$. in immune organs were decreased dose-dependently compared with the control groups at different time points. Their content decreased to the lowest levels in the high-dose groups compared with the control group $(P<0.05)$ except for the activity of GSH-Px in thymus on the 90th day, which the lowest level was appeared in the low-dose group. In contrast, MDA content in all of the $\mathrm{As}_{2} \mathrm{O}_{3}$-treated groups was higher than in the control group, correspondingly. And it reached its maximum value in high-dose groups.

\section{Histopathological analysis}

As shown in Figure 3, some representative pictures on the 90th day illustrated the $\mathrm{As}_{2} \mathrm{O}_{3}$-induced histological changes in immune organs. The thymus, spleen and BF tissues samples from control groups showed normal histological structures in morphology in Figure 3A, 3C and $3 \mathrm{E}$. Compared with that of control group, $\mathrm{As}_{2} \mathrm{O}_{3}$ treatment caused the number of white pulp lymphocytes of spleen decreased in high-dose group in Figure 3B, heterophils infiltration in thymus in high-dose group in Figure 3D. Follicles of BF were atrophic obviously in $\mathrm{As}_{2} \mathrm{O}_{3}$-treated group. At the same time, the boundary between cortex and medulla disappeared with a decreased number of lymphocytes, and connective tissue got significant hyperplasia in Figure 3F.

\section{Analysis of inflammatory mediators mRNA levels and iNOS protein level}

From the 30th to 90th days of age during the experiment, the mRNA levels of TNF- $\alpha$, PTGEs, COX2 , iNOS, NF- $\kappa$ B, IL- 6 and IL- 8 were increased dosedependently in treatment groups in three organs (Figures 4 and 5). Especially, levels in the medium and high-dose groups increased significantly compared with the corresponding control groups $(P<0.05)$ except the levels of IL-6 in BF as well as IL-8 in spleen and thymus on the 30th day, which showed no significant increase compared with the corresponding control groups $(P>0.05)$. On the 30 th day, the transcriptional levels of IL-1 $\beta$ and IFN- $\gamma$ in all these three immune organs reached their maximum values in the high-dose groups compared with the control groups $(P<0.05)$ (Figure 6). On the 60th and 90th days, they displayed decreases in a dose-dependent manner, and they reached the minimum values in the high-dose groups compared with the control groups $(\mathrm{P}<0.05)$. Protein expression level of iNOS was consistent with its mRNA level treated by $\mathrm{As}_{2} \mathrm{O}_{3}$ which showed significant increase compared with corresponding control groups in three organs $(P<0.05)$ (Figure 7$)$.

\section{Ultrastructural analysis}

As shown in Figure 8, some representative pictures (immune organs samples on the 90th day of the experiment) illustrated the $\mathrm{As}_{2} \mathrm{O}_{3}$-induced ultrastructural changes in the immune organs. Electron microscopy revealed normal immune organs ultrastructures in control groups on the 90th day (Figure 8A, 8B and 8C). In contrast, $\mathrm{As}_{2} \mathrm{O}_{3}$ treatment caused extensive immune organs damage on the 90th day. A number of cells displayed morphological characteristic of apoptosis, including markedly swollen mitochondria with the degeneration or loss of cristae, blebbing of the membranes with cytoplasmic vacuolation, cell shrinkage, and chromatin condensation. Moreover, nucleus had lost its regular structure and was condensed while the nuclear membrane had appeared to lose structural integrity (Figure 8D, 8E and 8F).

\section{TdT-mediated dUTP Nick End Labeling (TUNEL) Assay}

Effects of $\mathrm{As}_{2} \mathrm{O}_{3}$ treatment on apoptosis index in the immune organs have been presented in Figure 9. The number of apoptosis lymphocytes was significantly increased in high-dose groups compared with corresponding control groups $(P<0.05)$. Immune organs from each control group showed normal lymphocytes (Figure 8A, 8B and 8C), chicken treated with $2.5 \mathrm{mg} / \mathrm{kg}$ $\mathrm{BW} \mathrm{As}_{2} \mathrm{O}_{3}$ in the diet for 90 days showed more apoptotic lymphocytes in the immune organs significantly $(P<0.05)$ (Figure 8D, 8E and 8F) compared with the control group.

\section{Determination of apoptosis-related genes' mRNA levels}

To confirm the role of apoptosis in $\mathrm{As}_{2} \mathrm{O}_{3}$-induced injury, qRT-PCR was used to demonstrate change of mRNA levels of apoptosis-related genes in mitochondria apoptosis pathway (p53, Bcl-2, Bax, caspase-9, caspase-3) and death receptor apoptosis pathway (Fas and caspase-8) in $\mathrm{As}_{2} \mathrm{O}_{3}$ treated chickens (Figures 10 and 11). The mRNA levels of Bax, caspase- 9 and caspase- 3 in immune organs were increased dose-dependently on the 60th and 90th days and they increased to the maximum values in high-dose groups compared with the corresponding control groups $(P<0.05)$. However, the mRNA levels of p53 in spleen, BF and Fas in spleen and thymus, displayed no significant increases on the 30th days compared with the corresponding control groups $(P>0.05)$. The mRNA level of Bcl-2 in immune organs decreased at each $\mathrm{As}_{2} \mathrm{O}_{3}$ concentration and decreased to the lowest value in high-dose groups significantly compared with the corresponding control groups $(P<0.05)$. The mRNA level of caspase- 8 in the BF was decreased dosedependently, interestingly, it showed significant differences in the other two organs, which showed increased in a 
dose-dependent manner compared with the corresponding control groups $(P<0.05)$.

\section{Western blot analysis of apoptosis cytokines}

Western blot analysis of apoptosis cytokines was shown in the Figures 12 and 13. We found that protein expression levels of p53, Bax, caspase-9 and caspase-3 increased significantly compared with corresponding control groups in spleen, thymus and $\mathrm{BF}(P<0.05)$. Protein expression level of $\mathrm{Bcl}-2$ was consistent with its mRNA level treated by $\mathrm{As}_{2} \mathrm{O}_{3}$ which showed significant decrease compared with corresponding control groups in three organs $(P<0.05)$.
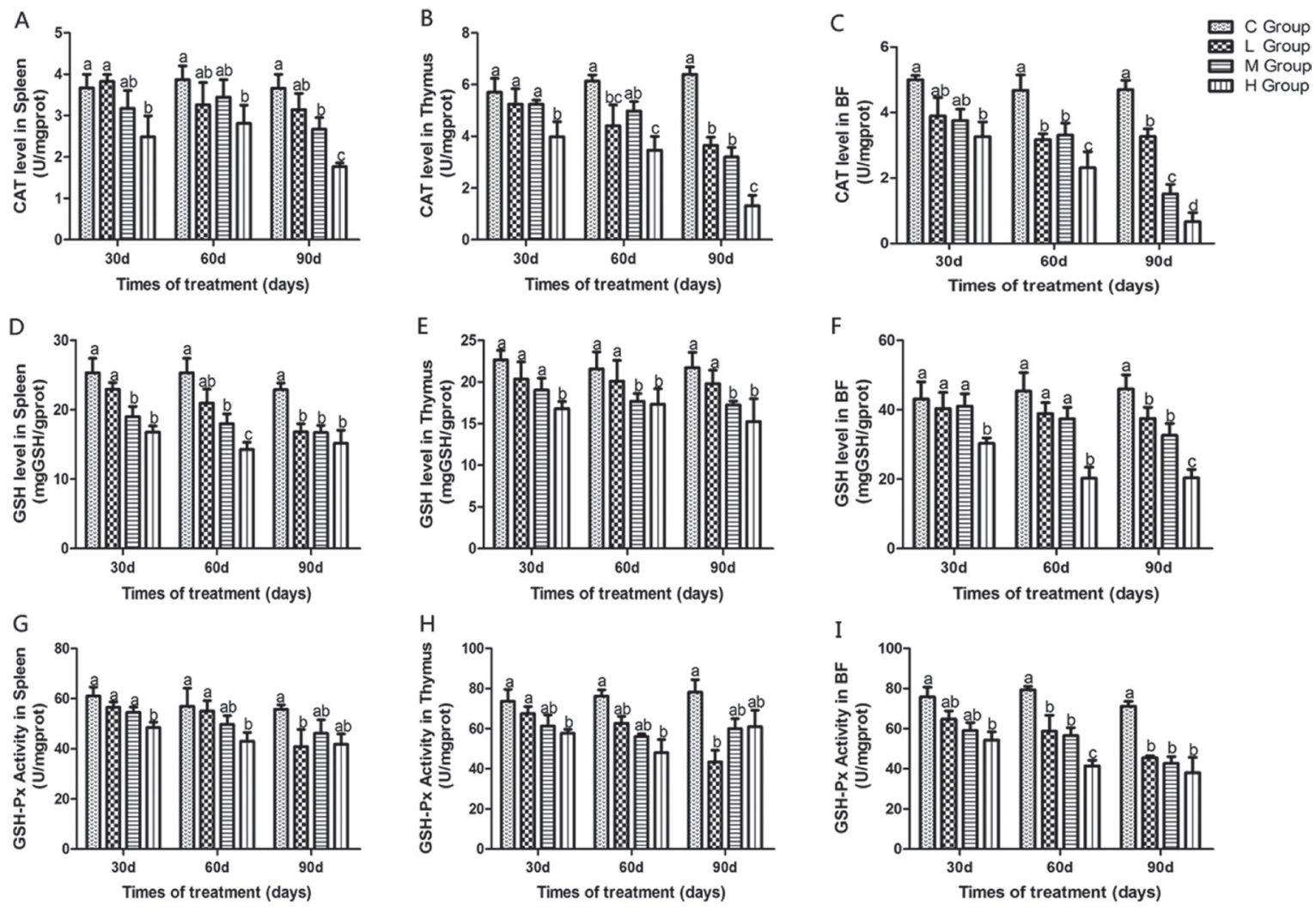

Figure 1: Effects of $\mathrm{As}_{2} \mathrm{O}_{3}$ on activities of CAT, GSH and GSH-Px at 30, 60 and 90 days. Bars sharing a common letter are not significantly different $(P>0.05)$ in the same group. Each value represents the mean $\pm \operatorname{SD}(n=6)$.
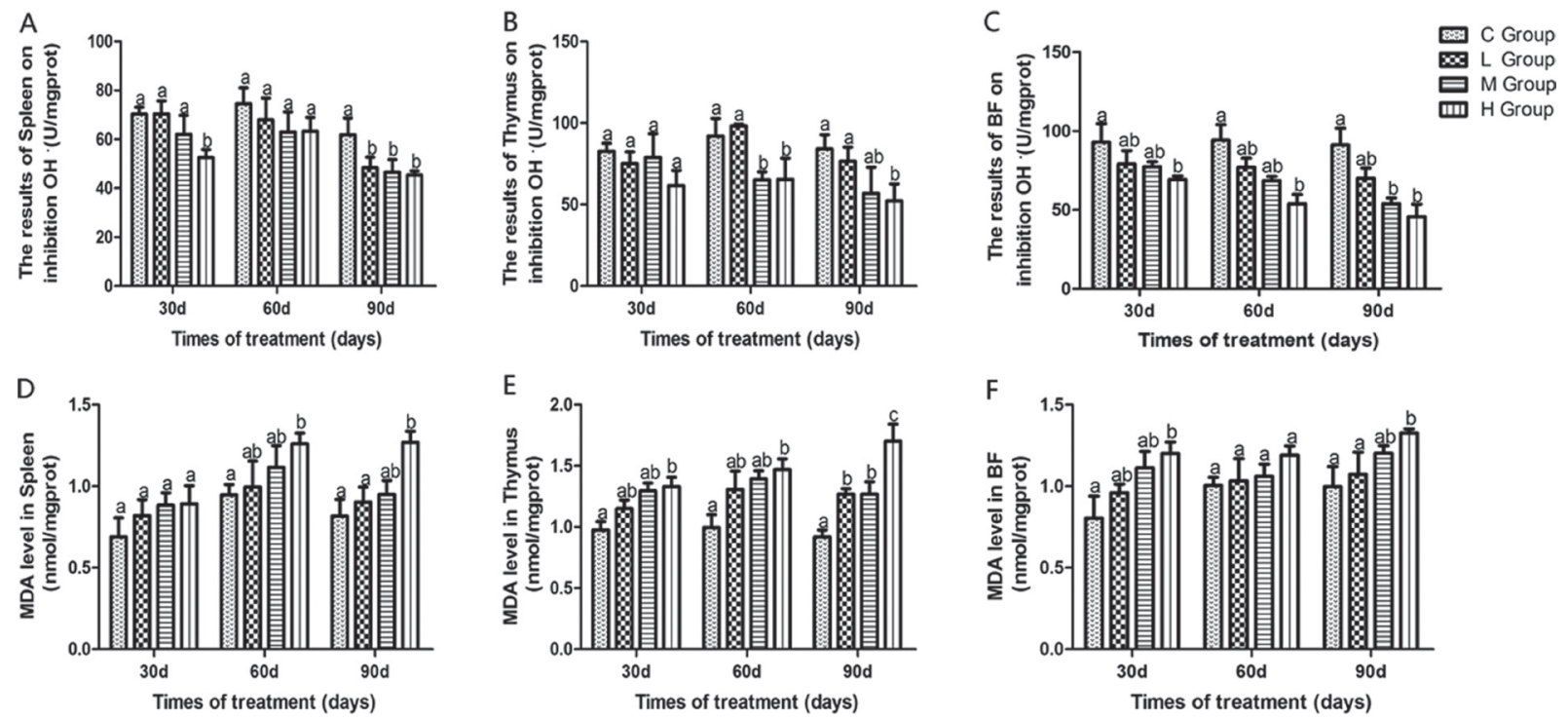

Figure 2: Effects of $\mathbf{A s}_{2} \mathbf{O}_{3}$ on ability of inhibition $\mathbf{O H}$. and content of MDA at 30, 60 and 90 days Bars sharing a common letter are not significantly different $(P>0.05)$ in the same group. Each value represents the mean $\pm \operatorname{SD}(n=6)$. 


\section{DISCUSSION}

Arsenic is a nonmetal element, which widely distributes in water, food, drugs, and minerals that tends to cycle in our living environment [34]. $\mathrm{As}_{2} \mathrm{O}_{3}$ is quite toxic and it can induce lipid peroxidation, one of the main markers of oxidative stress, which leads to cytotoxic effect [35]. In the present study, decreased levels of antioxidants such as CAT, GSH-Px, and GSH, and the ability to resist $\mathrm{OH}$. and an increased level of MDA were displayed in $\mathrm{As}_{2} \mathrm{O}_{3}$-treated chickens (Figures 1 and 2). The above results indicated that $\mathrm{As}_{2} \mathrm{O}_{3}$ exposure inhibited the antioxidant defense system, which led to oxidative damage and disturbances of metabolism and function in chicken immune organs. NO et al. [36] reported that airway oxidative inflammation may contribute to systemic inflammation through upregulation of Th17 immune responses in blood /liver and hepatic oxidative stress, namely, oxidative stress has a direct relationship with inflammation. Chickens are sensitive to $\mathrm{As}_{2} \mathrm{O}_{3}$, and a low dosage of $\mathrm{As}_{2} \mathrm{O}_{3}$ can induce immunosuppression, which showed the increases of NF- $\mathrm{KB}, \mathrm{TNF}-\alpha, \mathrm{IL}-6$ and IL-8 [11]. As revealed by histopathological analysis (Figure 3), an obvious atrophy of follicles in BF, infiltration of heterophils in thymus and decreased lymphocytes, were consistently observed in the $\mathrm{As}_{2} \mathrm{O}_{3}$-treated groups, which were in line with earlier researches [20,37]. Results also displayed that the mRNA levels of TNF- $\alpha$, PTGEs,
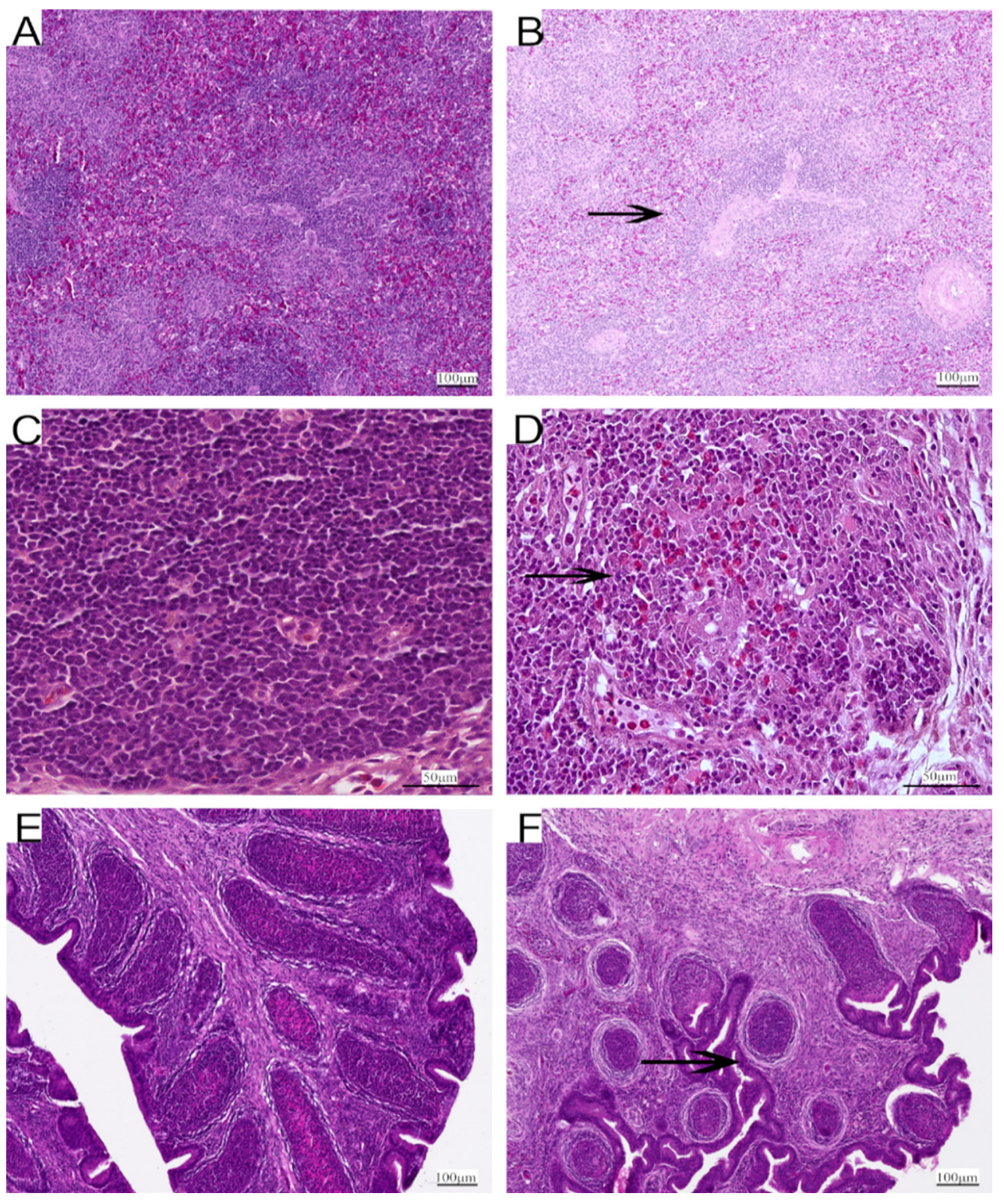

Figure 3: Representative photomicrographs of H\&E-stained immune organs at 90 days Control group from spleen (A), thymus (C) and $\mathrm{BF}(\mathbf{E})$, high $-\mathrm{As}_{2} \mathrm{O}_{3}$ group from spleen $(\mathbf{B})$, thymus $(\mathbf{D})$ and BF $(\mathbf{F})(\times 400)$ Black arrows stand for decreased lymphocytes, infiltration of heterophils in thymus and obvious atrophy of follicles in BF. Scale bars - $100 \mu \mathrm{m}$ (a, b, e and f), $50 \mu \mathrm{m}$ (c and d). 
COX-2, iNOS, NF- $\mathrm{B}$, IL-6 and IL-8 were increased in treatment groups in three organs (Figures 4 and 5), which were consistent with previous study [38]. The deleterious effects of $\mathrm{As}_{2} \mathrm{O}_{3}$ on anti-oxidative systems and immune defense have been suggested in chicken immune organs from above results.

Higher level of $\mathrm{As}_{2} \mathrm{O}_{3}$ depresses the activities of antioxidant enzymes, and then free radicals accumulate in the immune organs and induce the lipid peroxidation of the membrane. It is reasonable to propose that oxidative damage could occur in mitochondria and cause the release of proapoptotic proteins into the cytosol, which results in cellular apoptosis. Then, we tried to demonstrate apoptosis in the immune organs which occurred secondary to oxidative stress and inflammation, but it should be further clarified that if mitochondria or death receptor apoptotic pathways were both involved in this apoptotic procedure. Our study is the first to answer this question by using a chicken model suffering from subchronic arsenism.

In the present study, we performed an ultrastructure assay of chicken immune organs and found that $\mathrm{As}_{2} \mathrm{O}_{3}$ exposure to chicken caused typical features of apoptosis (Figure 7). In accordance with these definite morphological changes, apoptosis was further confirmed by TUNEL assay, which revealed the increased number of apoptotic cells in subchronic arsenism test (Figure 8). It indicated that $\mathrm{As}_{2} \mathrm{O}_{3}$ plays an important role in the induction of apoptosis in immune organs of chicken. Mitochondria
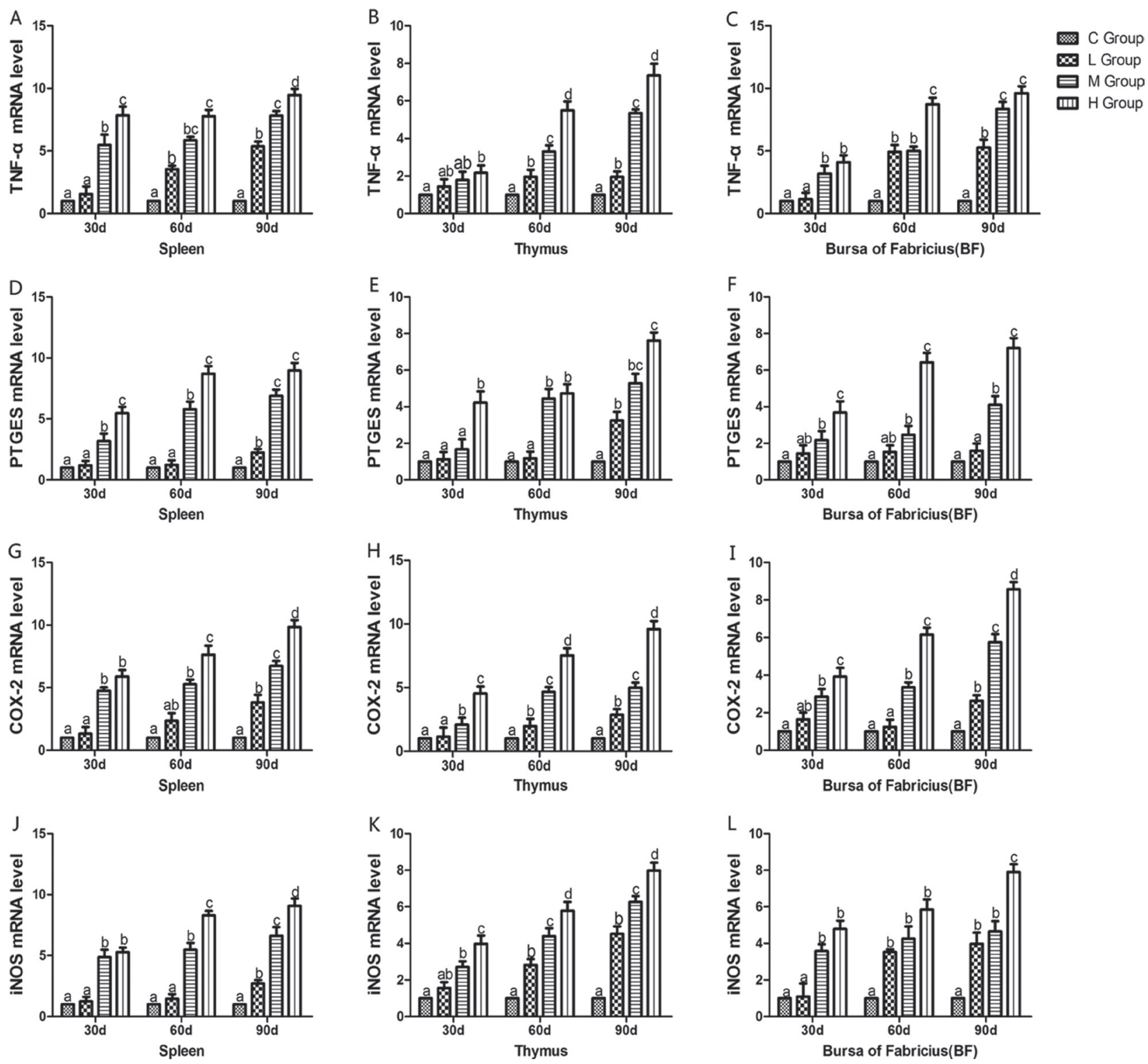

Figure 4: Effects of $\mathrm{As}_{2} \mathrm{O}_{3}$ on mRNA expression of TNF- $\alpha$, PTGEs, COX-2, iNOS gene at 30,60 and 90 days. Bars sharing a common letter are not significantly different $(P>0.05)$ in the same group. Each value represents the mean $\pm \operatorname{SD}(n=6)$. 

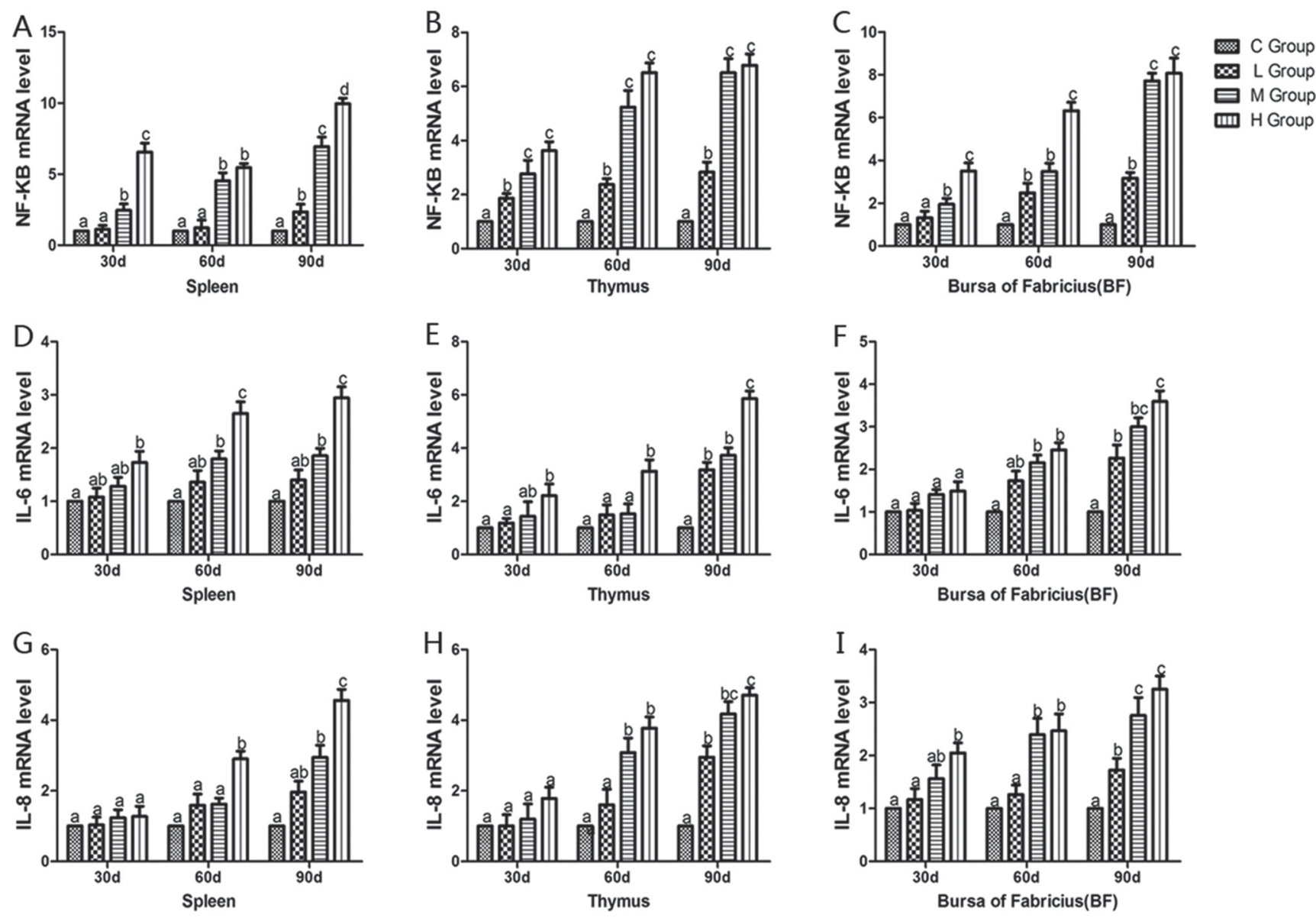

Figure 5: Effects of $\mathrm{As}_{2} \mathrm{O}_{3}$ on mRNA expression of NF-кB, IL-6 and IL-8 gene at 30, 60 and 90 days. Bars sharing a common letter are not significantly different $(P>0.05)$ in the same group. Each value represents the mean $\pm \mathrm{SD}(n=6)$.
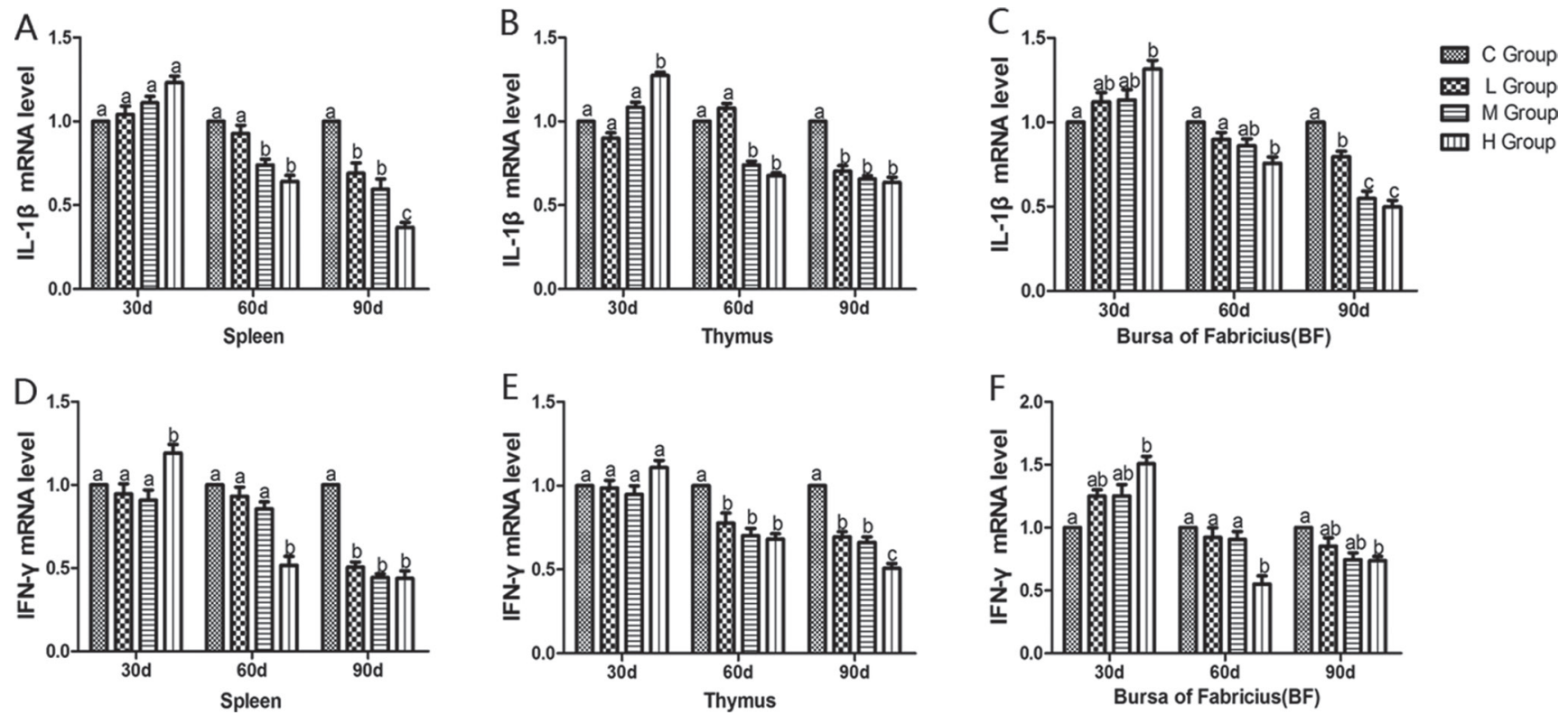

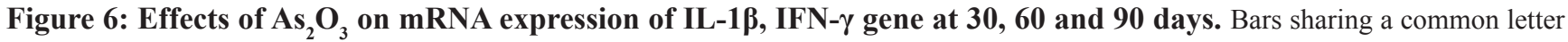
are not significantly different $(P>0.05)$ in the same group. Each value represents the mean $\pm \mathrm{SD}(n=6)$. 
Spleen

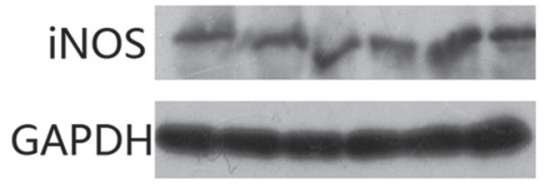

Thymus

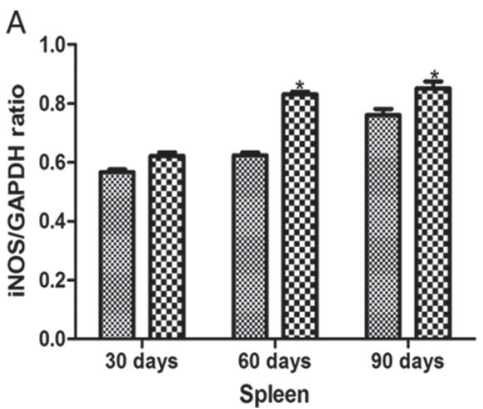

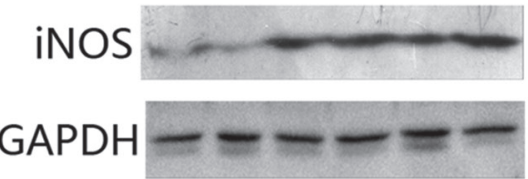

$\mathrm{BF}$
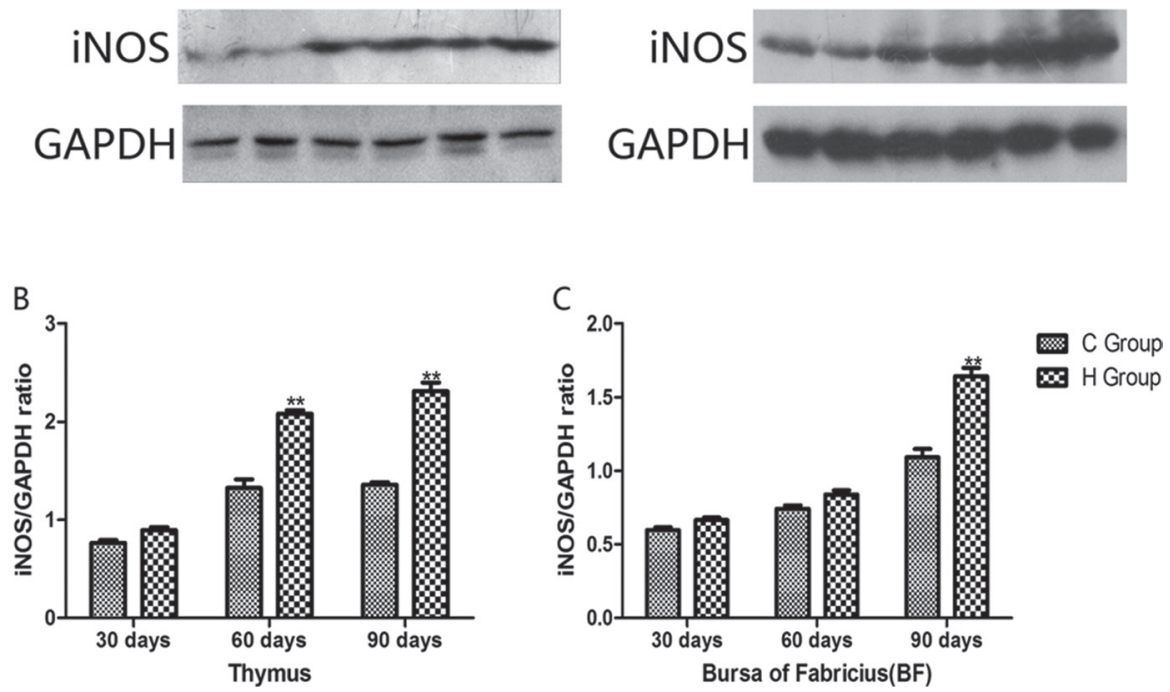

Figure 7: Effects of $\mathrm{As}_{2} \mathrm{O}_{3}$ on protein expression of iNOS at 30,60 and 90 days $* P<0.05$, compared with the control group. Data are presented with the mean $\pm \mathrm{SD}$.
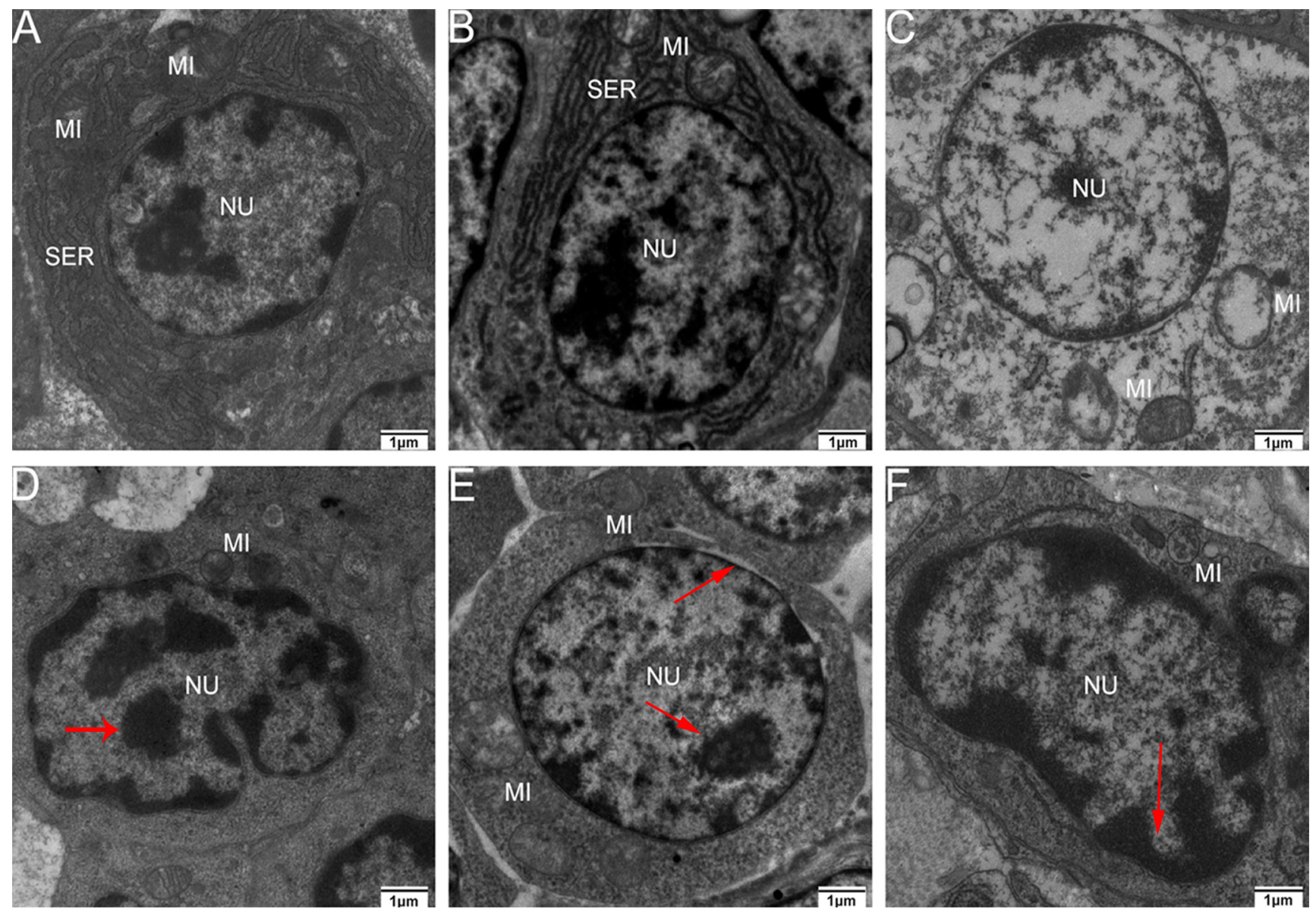

Figure 8: Transmission electron microscopy of immune organs at 90 days of age Control group from spleen (A), thymus (B) and BF $(\mathbf{C})$, high $-\mathrm{As}_{2} \mathrm{O}_{3}$ group from spleen $(\mathbf{D})$, thymus $(\mathbf{E})$ and $\mathrm{BF}(\mathbf{F})(\times 2000)$ Red arrows stand for nucleus with lost structural integrity and chromatin condensation. Key: $M I$, mitochondria; SER, smooth endoplasmic reticulum; and $N U$, nucleus. 
pathway involves initial mitochondrial perturbation resulted from cellular stress or cytotoxicity [39]. Followed by the release of apoptogenic factors such as cytochrome $\mathrm{c}$ and apoptosis-inducing factor, the activation of initiator caspase-9 and effector caspase-3 can be also triggered by oxidative [40]. The Bcl-2 protein family, which locates mainly on the outer membrane of mitochondria, is the major regulators and effectors of the mitochondria pathway, it can be categorized into the antiapoptotic proteins (such as Bcl-2-like proteins), and the pro-apoptotic proteins (such as Bax-like proteins) [41]. Moreover, p53 could participate in apoptosis through mitochondrial pathway by up-regulating the expression of
Bax and down-regulating the expression of Bcl-2 [42]. In agreement with these theories, the increases in caspase-9, caspase-3, p53 and Bax as well as the decrease in Bcl-2 on protein contents and mRNA expression levels in our study suggested that apoptosis of immune organs was induced by $\mathrm{As}_{2} \mathrm{O}_{3}$ in $0.625 \mathrm{mg} / \mathrm{kg} \mathrm{BW}$ and over, which by means of activating the mitochondrial pathway.

As a pro-apoptotic protein, caspase- 3 is activated in the apoptotic cell both by mitochondria pathway and death receptor apoptotic pathway, and executes the apoptotic process [43]. Thus, we investigated the relative mRNA expressions of genes correlated with death receptor apoptotic pathway, such as Fas, which requires binding
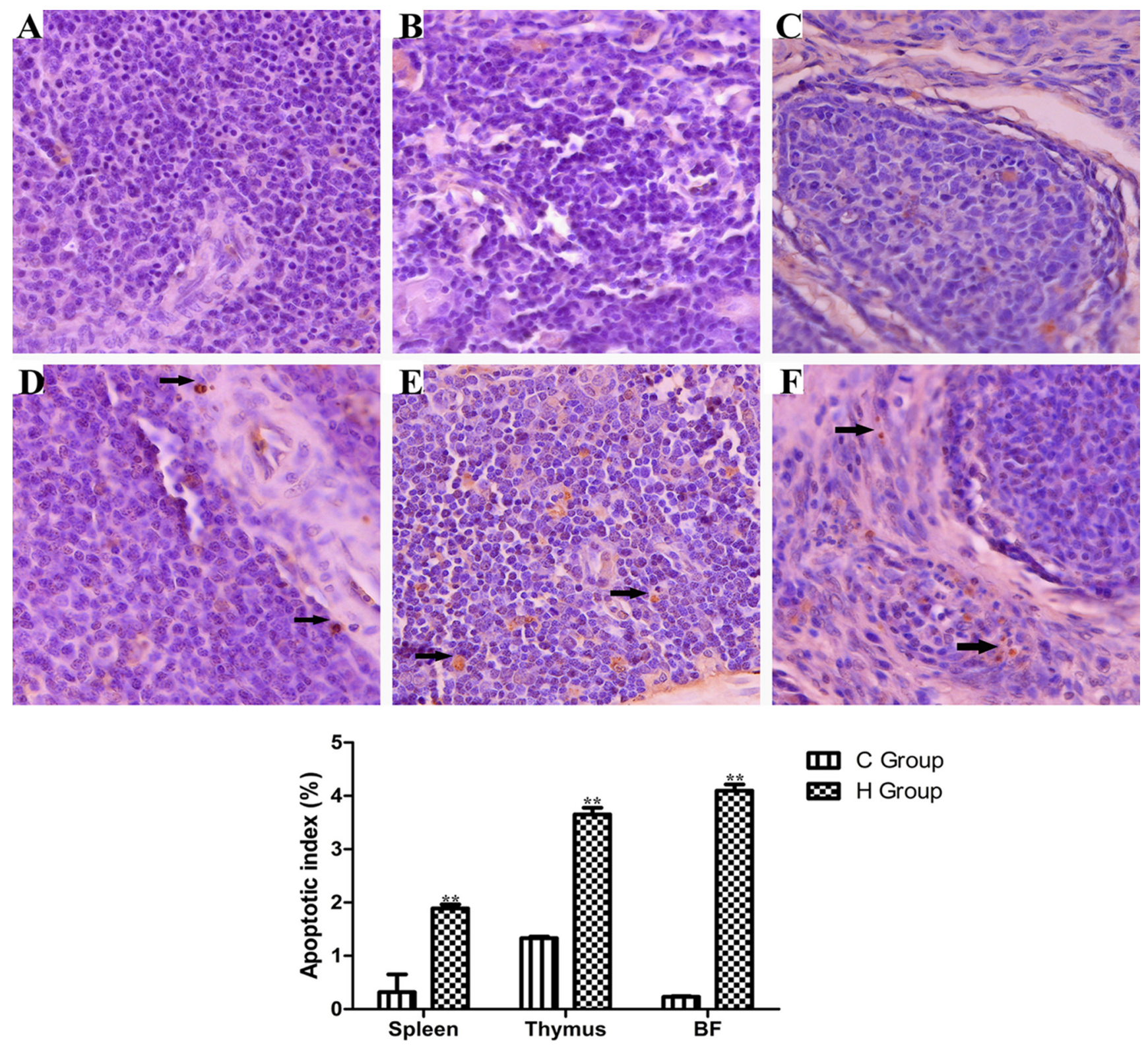

Figure 9: TUNEL staining (counterstained with hematoxylin, $\times 400)$ of dimmune organs at 90 days of age Control group from spleen (A), thymus $(\mathbf{B})$ and $\mathrm{BF}(\mathbf{C})$, high- $\mathrm{As}_{2} \mathrm{O}_{3}$ group from spleen $(\mathbf{D})$, thymus $(\mathbf{E})$ and $\mathrm{BF}(\mathbf{F}) * * P<0.01$, compared with the control group. Data are presented with the mean $\pm \mathrm{SD}(n=6)$ Black arrows stand for apoptotic cells with brown-stained nuclei. 
to the Fas ligand (FasL) [44]. Yang et al. [45] proved that compared with control, treatment with $\mathrm{As}_{2} \mathrm{O}_{3}$ at a level of $2 \mu \mathrm{M}$ and $4 \mu \mathrm{M}$ for 48 hours, resulted in increase of Fas gene expression by $28.31 \%$ and $56.74 \%$, respectively. On the other hand, TNF- $\alpha$ can induce apoptosis through TNF- $\alpha$ receptor-mediated activation of Fas-associated death domain (FADD) protein, which brings about activation of caspase-8 [46]. Poulaki [47] reported that caspase- 8 got methylation resulting in gene silencing which decreased expression of caspase-8, and prevented human retinoblastoma cells from apoptosis. In particular, the liberated NF- $\mathrm{BB}$ dimers enter nucleus, in which they regulate transcription of diverse genes to encode cytokines, growth factors, cell adhesion molecules, proand anti-apoptotic proteins [48]. In this experiment, mRNA levels of Fas, TNF- $\alpha$, caspase- 8 and NF- $\kappa$ B increased significantly compared with corresponding control groups in spleen and thymus on the 60th and 90th days. Our results demonstrated that the excessive apoptosis induced by $\mathrm{As}_{2} \mathrm{O}_{3}$ involved the death receptor pathway. Interestingly, mRNA levels of Fas displayed no significant increase in spleen (Figure 11G) and thymus
(Figure $11 \mathrm{H}$ ) compared with control groups on the 30th day $(P>0.05)$. Moreover, mRNA levels of caspase- 8 in $0.625,1.25$ and $2.5 \mathrm{mg} / \mathrm{kg} \mathrm{BW}$ groups showed lower values than that of control groups in the BF (Figure 11L), which indicted that death receptor apoptotic pathway wasn't activated until the 30th day in spleen and thymus. As for BF, this apoptotic pathway even hasn't been activated by $\mathrm{As}_{2} \mathrm{O}_{3}$ in present study. Our result is in line with previous study which showed the expressions of Fas, FasL, FADD and caspase- 8 were no difference between the Aflatoxin $B_{1}$ group and the control group, which evidenced that death receptor apoptotic pathway may not contribute to the excessive cell death of BF cells [41]. In summary, mitochondria apoptosis pathway plays a more extensive role than death receptor apoptotic pathway in chicken immune organs suffering from subchronic arsenism, and the latter pathway might be inhibited in BF cells, its exact mechanism needs further study.

Nevertheless, we also found that the mRNA levels of IL-1 $\beta$ and IFN- $\gamma$ showed the highest value in $\mathrm{H}$ group on the 30th day and significant decrease on the 60th and 90th days following $\mathrm{As}_{2} \mathrm{O}_{3}$ exposure in immune
A
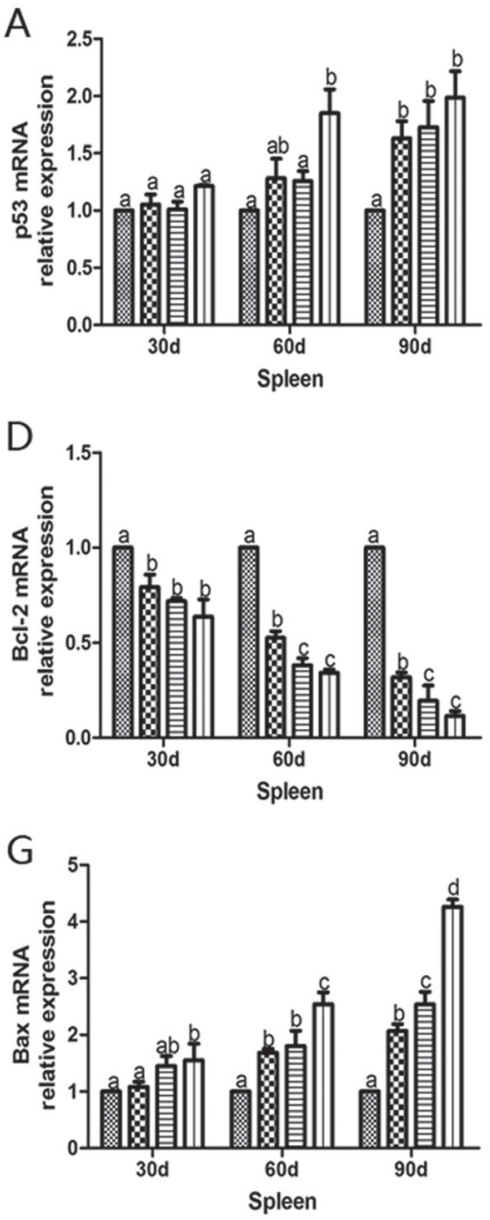

B

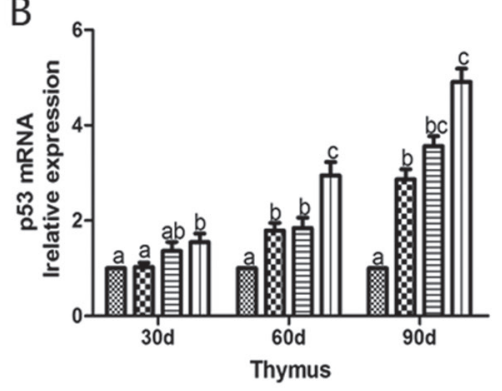

E

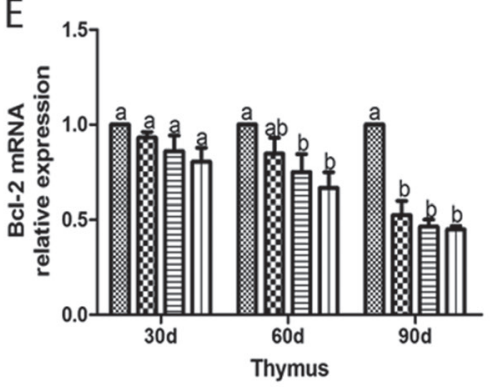

$\mathrm{H}$

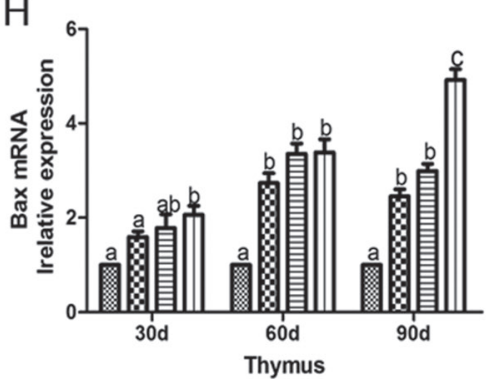

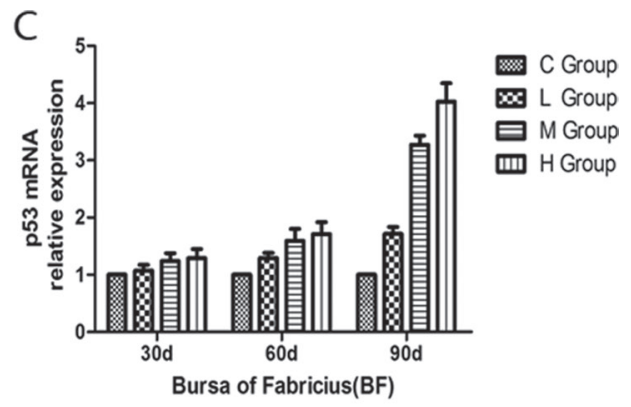

$\mathrm{F}$

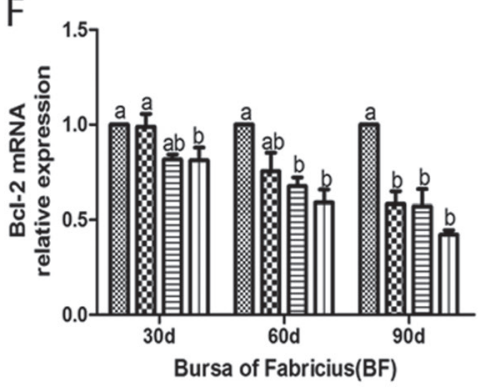

I

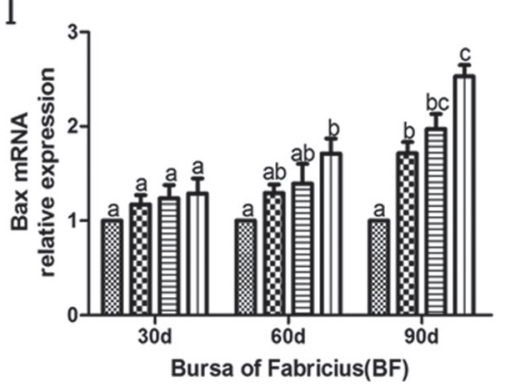

Figure 10: Effects of $\mathrm{As}_{2} \mathrm{O}_{3}$ on mRNA expression of p53, Bcl-2 and Bax gene at 30, 60 and 90 days. Bars sharing a common letter are not significantly different $(P>0.05)$ in the same group. Each value represents the mean $\pm \operatorname{SD}(n=6)$. 
organs compared with corresponding control groups $(P<0.05)$ (Figure 6). Lynch et al. suggested that Fas/ FasL mediated activation of $\mathrm{T}$ lymphocyte apoptosis, controlled the inflammatory response to a certain extent, so as to avoid the occurrence of sustained, strong inflammatory response [49]. It was also consistent with Matzinger's theory that apoptosis cells do not stimulate the inflammatory response because of the lack of some risky signals [50]. Indeed, our results directly displayed that apoptosis cells do restrain the inflammatory response after subchronic arsenism, conversely.

In conclusion, the present study demonstrated that mitochondria and death receptor apoptosis pathways could be triggered in immune organs of chickens suffering from dietary $\mathrm{As}_{2} \mathrm{O}_{3}$ (Figure 14), meanwhile, oxidative stress and immune injury might be an important driver of excessive apoptosis in this study.

\section{MATERIALS AND METHODS}

\section{Animals and treatment}

A total of 72 one-day-old male Hy-line chickens were randomly divided into four groups (18 chickens per group). Chickens were housed in cages with electrical heaters, and provided with water by PVC pipeline and nipple drinkers as well as under-mentioned experimental diets ad libitum for 90 days. The composition of the diet
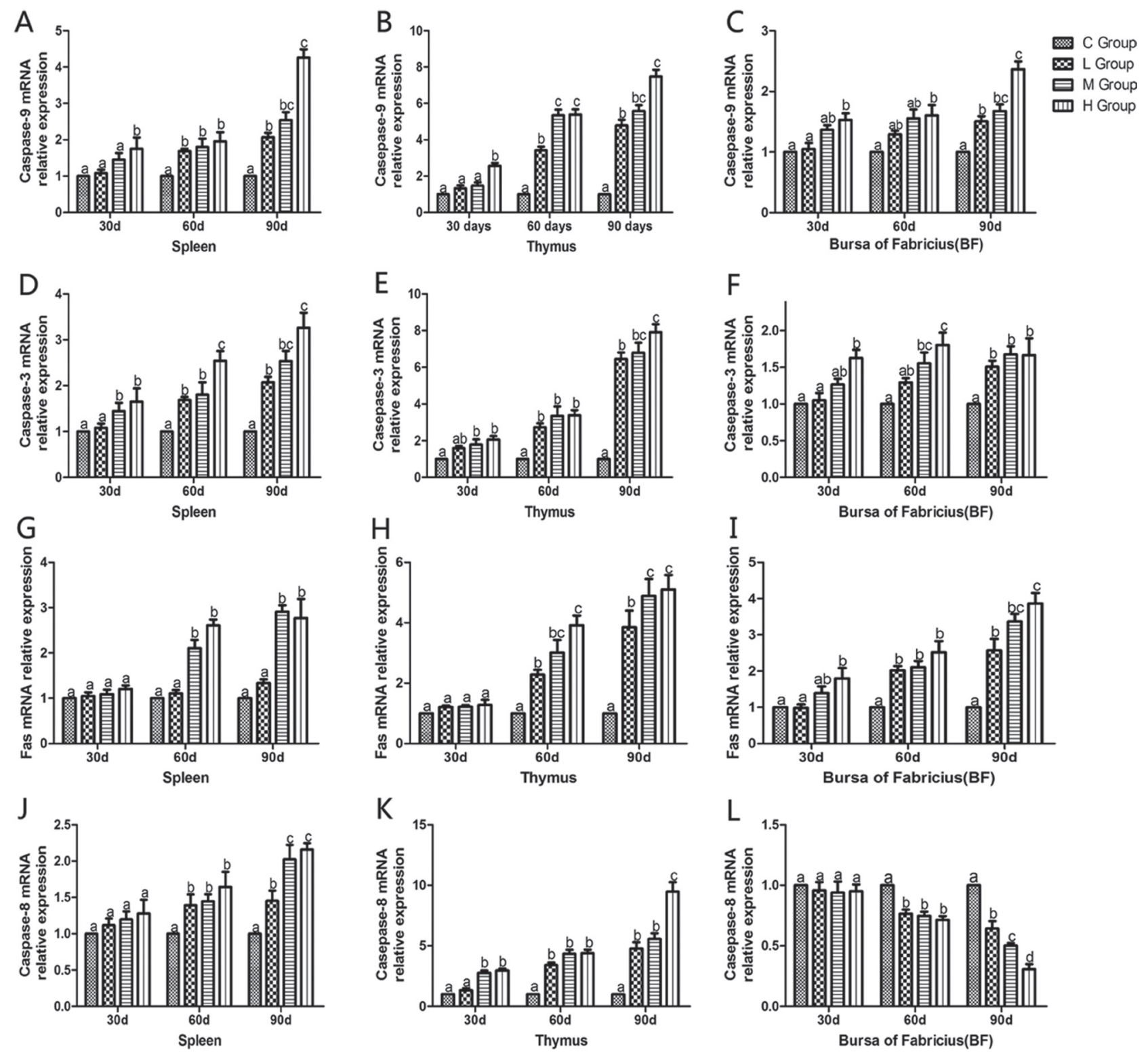

Figure 11: Effects of $\mathrm{As}_{2} \mathrm{O}_{3}$ on mRNA expression of caspase-9, caspase-3, Fas and caspase-8 gene at 30 , 60 and 90 days. Bars sharing a common letter are not significantly different $(P>0.05)$ in the same group. Each value represents the mean $\pm \mathrm{SD}$ $(n=6)$. 
was: Maize, grains $421 \mathrm{~g} / \mathrm{kg}$; wheat, grains $120 \mathrm{~g} / \mathrm{kg}$; full fat soy $180 \mathrm{~g} / \mathrm{kg}$; pea $100 \mathrm{~g} / \mathrm{kg}$; wheat bran $80 \mathrm{~g} / \mathrm{kg}$; limestone $80 \mathrm{~g} / \mathrm{kg}$; dicalcium phosphate $15 \mathrm{~g} / \mathrm{kg}$ and sodium chloride $4 \mathrm{~g} / \mathrm{kg}$. This diet met the minimum requirements for energy and nutrients for chicken and without influencing results [51]. The highest dose of sub-chronic toxicity test can use $1 / 20$ to $1 / 5$ of the median lethal dose $\left(\mathrm{LD}_{50}\right)$ [Supplementary Appendix 1], and median lethal dose of arsenic for chicken was $50 \mathrm{mg} / \mathrm{kg}$ BW [Supplementary Appendix 2]. To observe the dose-dependent dynamic change, we set the four groups of different dose levels: a control group $(0 \mathrm{mg} / \mathrm{kg} \mathrm{BW})$, a low $\mathrm{As}_{2} \mathrm{O}_{3}$-treated group $(0.625 \mathrm{mg} / \mathrm{kg} \mathrm{BW}$, corresponding $7.5 \mathrm{mg} / \mathrm{kg}$ feed $)$, a middle $\mathrm{As}_{2} \mathrm{O}_{3}$-treated group $(1.25 \mathrm{mg} / \mathrm{kg} \mathrm{BW}$, corresponding 15 $\mathrm{mg} / \mathrm{kg}$ feed), a high $\mathrm{As}_{2} \mathrm{O}_{3}$-treated group $(2.5 \mathrm{mg} / \mathrm{kg} \mathrm{BW}$, corresponding $30 \mathrm{mg} / \mathrm{kg}$ feed). $\mathrm{As}_{2} \mathrm{O}_{3}$ was added into the food to make supplements according to the chicken median lethal dose of $\mathrm{As}_{2} \mathrm{O}_{3}$. Based on the mentioned method, we published some studies on arsenic exposure caused the changes of oxidative stress and heat shock in chicken $[12,13] . \mathrm{As}_{2} \mathrm{O}_{3}$ was purchased from the New Technology Development Company, CHINA AGR UNIV. Animal studies, including animal care and all experimental procedures, were in accordance with the Animal Welfare Guidelines of Northeast Forestry University and the inhouse guidelines of the Institutional Animal Care and Use Committee in Harbin, China. Animal experiment protocols were reviewed and approved by the Animal Care, Use and Ethics Committee at Northeast Forestry University (approval no. UT-31; 20 June 2014).

To observe the time-dependent dynamic change, we chose three time points $(30,60$ and 90 days of age) for
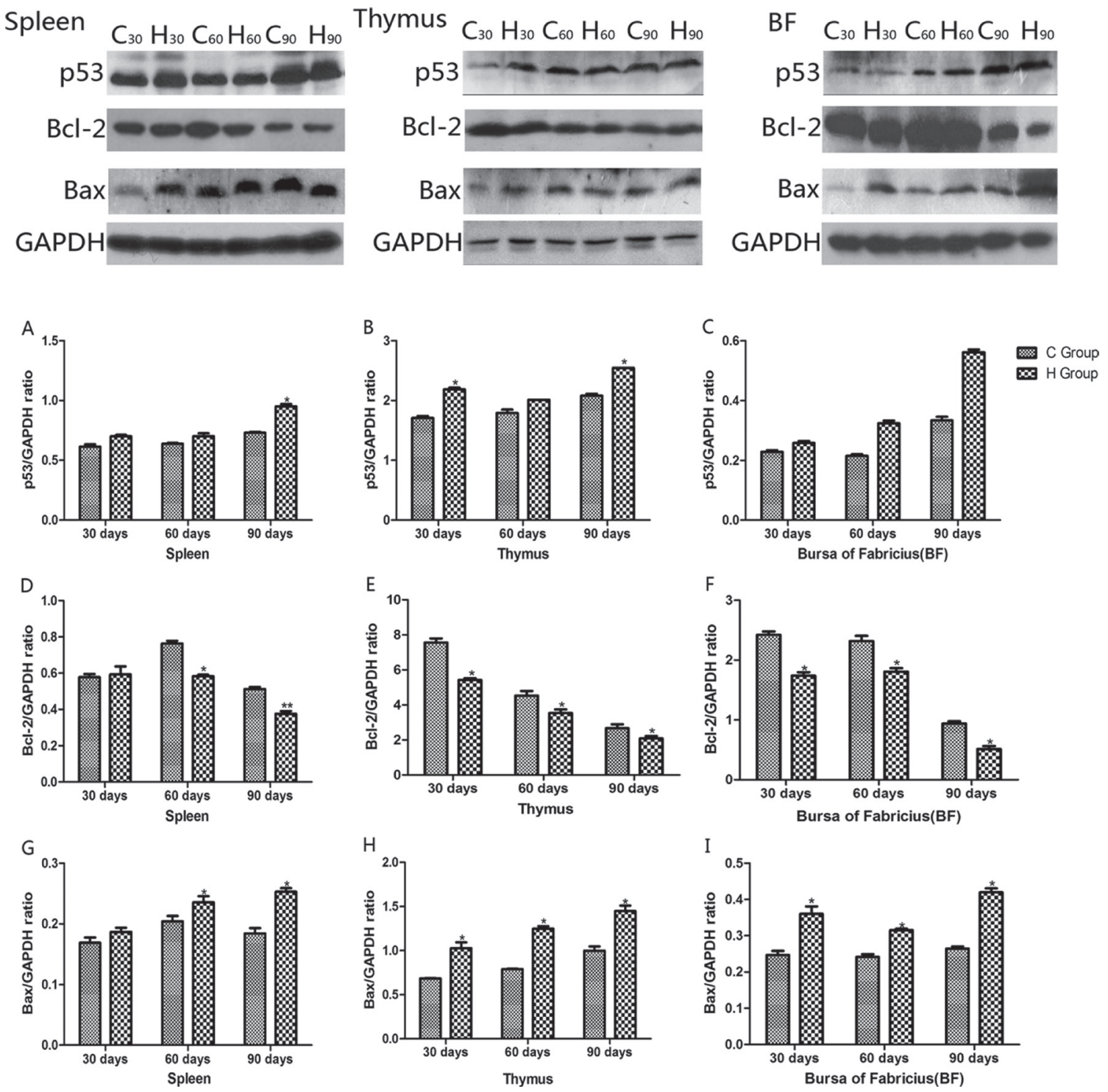

Figure 12: Effects of $\mathrm{As}_{2} \mathrm{O}_{3}$ on protein expression of p53, Bcl-2 and Bax at 30, 60 and 90 days $* P<0.05$, compared with the control group. Data are presented with the mean $\pm \mathrm{SD}$. 
examining histopathological injury, immune, antioxidant and apoptosis parameter changes. On the 30th, 60th, and 90th days, six chickens in each group were selected randomly. Chickens were anesthetized and euthanized using injection of sodium pentobarbital (30 mg/kg BW), immune organs (spleen, thymus, and BF) were immediately excised, rinsed with ice-cold $0.9 \% \mathrm{NaCl}$ solution. They were dried on filter paper and then marked.

\section{Determination of antioxidant enzyme activities and MDA levels}

CAT, GSH, GSH-Px, ability to resist $\mathrm{OH}$. and MDA levels in immune organs were determined in supernatants after isolated from chicken according to the method of the manufacturer's protocol of detection kits respectively (Nanjing Jiancheng Bioengineering Institute, Nanjing, China). Briefly, the activities of CAT, GSH, GSH-Px, ability to resist $\mathrm{OH}$. and MDA level in immune organs were measured at $405 \mathrm{~nm}, 420 \mathrm{~nm}, 412 \mathrm{~nm}, 600 \mathrm{~nm}$ and $532 \mathrm{~nm}$ respectively.

\section{Histological observation}

The immune organs were removed, fixed in $4 \%$ paraformaldehyde, dehydrated in ethanol and embedded in paraffin. Serial slices at $5 \mu \mathrm{m}$ thickness were prepared and stained with haematoxylin and eosin (H\&E), and examined by light microscopy.

\section{Quantitative real-time PCR}

For the RNA quantification, immune organs (50 mg tissue; $n=6$ /group.) were homogenized in liquid nitrogen with a mortar and pestle. According to the method described in the reference [13], total RNA was isolated from immune organs' powders using RNAiso Plus reagent (Takara, China) according to the manufacturer's instructions. The concentration of RNA was measured by means of a spectrophotometer at $\mathrm{OD}_{260 / 280}$ ratio and then reversetranscribed to cDNA using the PrimeScript RT Reagent Kit (Takara, China). Synthesised cDNA was diluted ten times with sterile water and stored at $-80^{\circ} \mathrm{C}$ before use.

Specific primers used for amplification were shown in Table 1. The relative mRNA levels of cytokines- and apoptosis-related genes were performed on a BIOER Line Gene 9600 Real-Time PCR System (Hangzhou, China) and determined with the FastStart Universal SYBR Green Master reagents (Roche, USA). The detailed conditions of PCR protocol and calculation method of each gene relative mRNA abundance are indicated in our previous research [13].

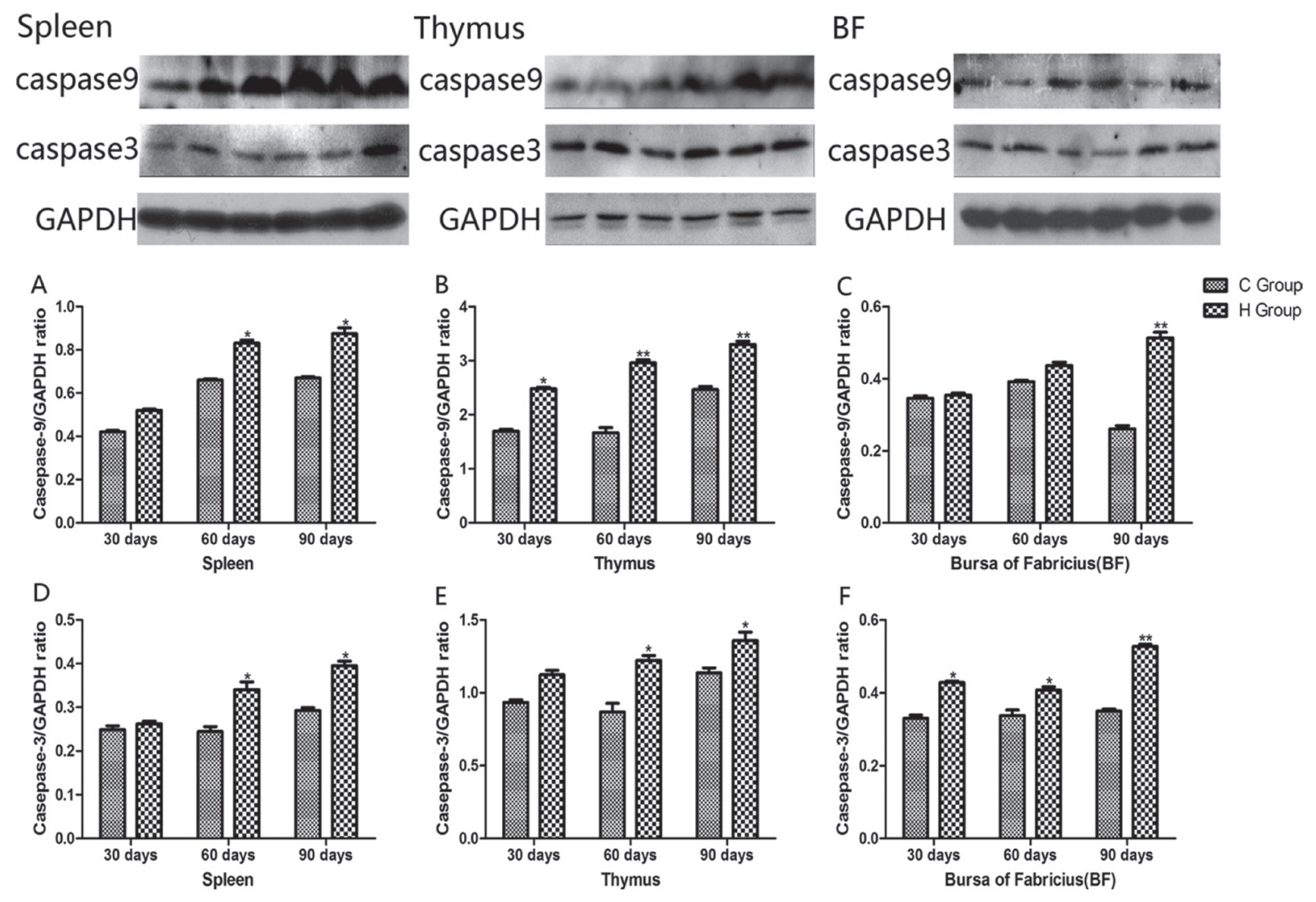

Figure 13: Effects of $\mathrm{As}_{2} \mathrm{O}_{3}$ on protein expression of caspase-9 and caspase-3 at 30, 60 and 90 days $* P<0.05$, compared with the control group. Data are presented with the mean $\pm \mathrm{SD}$. 


\section{Electron microscopy}

The immune organs (size: $1.0 \mathrm{~mm} \times 1.0 \mathrm{~mm} \times$ $1.0 \mathrm{~mm}$ ) were fixed immediately in $2.5 \%$ glutaraldehyde phosphate-buffered saline (v/v, pH 7.2), post-fixed in $1 \%$ osmium tetroxide (v/v) and stained with $4.8 \%$ uranyl acetate following dehydration. The samples were washed in propylene oxide and impregnated with epoxy resins. The semi-fine sections were contrasted with uranyl acetate and lead citrate for study via microscopy. The microphotographs were taken with a transmission electron microscope.

\section{In situ apoptosis detection}

The samples were treated according to the manufacturer's protocol for the Colorimetric TUNEL Apoptosis Assay Kit (Takara, China). Quantitative evaluation of the apoptosis index was performed by manual counting of positively stained nucleus at 400 magnification. Apoptosis was determined by counting at least 100 cells from 5 to 6 sections of each immune tissue. Results were expressed as the percentage of TUNELpositive cells among the total number of cells counted.

\section{Western blot analysis of apoptosis-related genes}

For the protein quantification, a total of $50 \mathrm{mg}$ tissue for each sample was rinsed in saline, cut and then homogenised in low intensity SDS Lysis Buffer (Beyotime, China). The homogenate was centrifuged, and supernatant was collected and determined using BCA protein assay kits (Thermo Scientific, USA).

For the western blot, the method was referred to our previous study [12]. Briefly, protein extracts (50 $\mathrm{mg}$ ) were subjected to $12 \%$ SDS-polyacrylamide gels to separate target protein and then electrophoretically transferred to nitrocellulose membranes in Trisglycine buffer. Membranes were blocked with 5\% skim milk at $37{ }^{\circ} \mathrm{C}, 50 \mathrm{rpm}$ for $4 \mathrm{~h}$, and incubated overnight with diluted primary antibody. To verify equal loading of samples, membranes were also incubated with GAPDH antibody (Beyotime, China). Then, membranes were incubated with horseradish peroxidase (HRP)labeled Goat Anti-rabbit IgG (Beijing Biosynthesis Biotechnology, Co., LTD, China) at $37^{\circ} \mathrm{C}, 50 \mathrm{rpm}$ for $1 \mathrm{~h}$. Signals were detected by ECL western blotting detection kit (Thermo Scientific, USA). Target protein

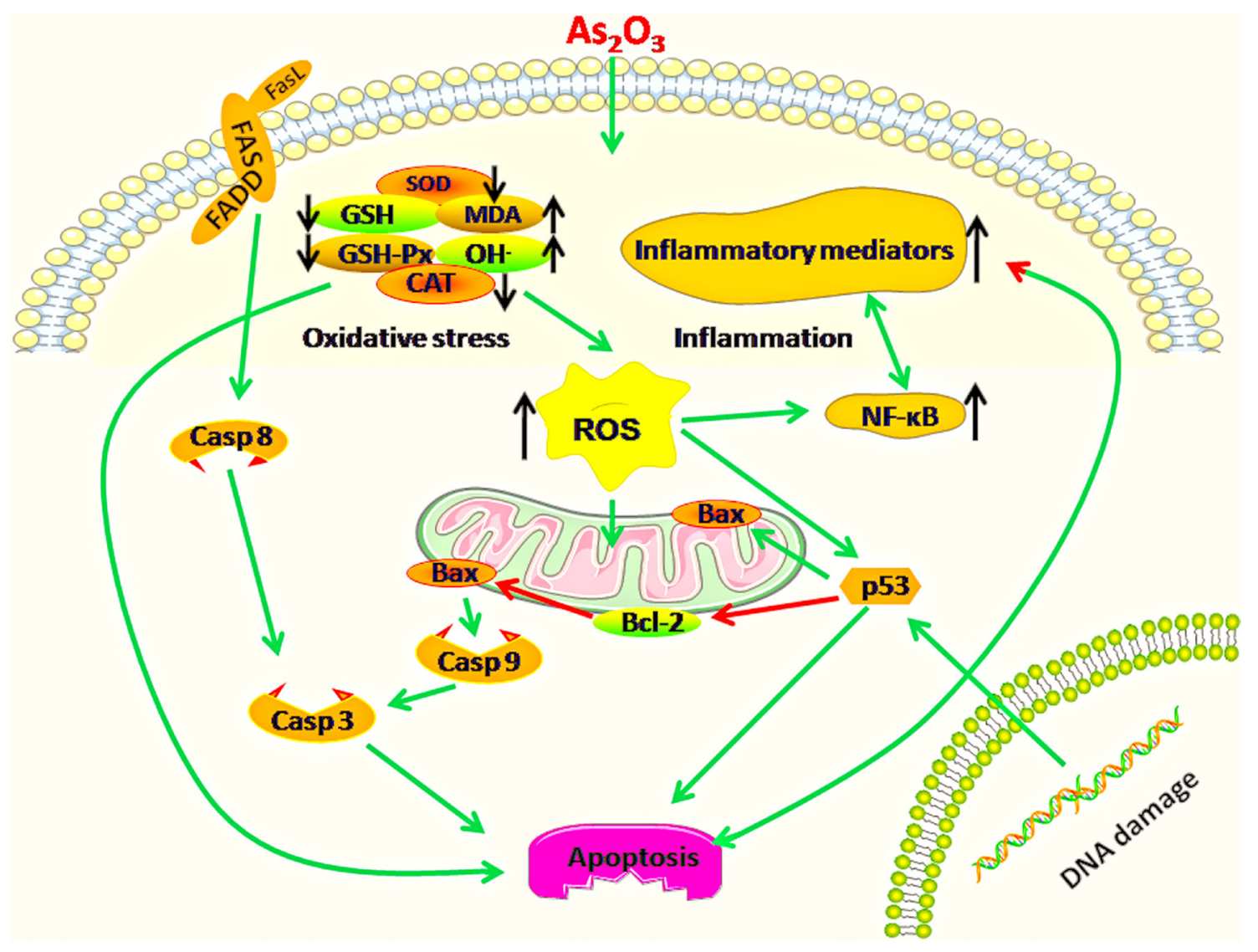

Figure 14: Diagram depicts the toxic effect of arsenic trioxide on chicken immune organs: Mitochondria and death receptor apoptosis pathways are activated because of excessive apoptosis in immune organs of chickens suffering from subchronic arsenism, and oxidative stress as well as subsequent inflammatory is a crucial driver during $\mathrm{As}_{2} \mathrm{O}_{3}$ exposure. Green arrows mean promotion, red arrows mean inhibition. "†"means up-regulation, " $\downarrow$ "means down-regulation. 
Table 1: A list of primers in qRT-PCR analysis of mRNA expression of the target genes

\begin{tabular}{|c|c|c|c|}
\hline Genes & $\begin{array}{l}\text { GenBank } \\
\text { accession }\end{array}$ & Primer sequence $\left(5^{\prime} \rightarrow 3^{\prime}\right)$ & Product size \\
\hline$N F-\kappa B$ & NM205134 & $\begin{array}{l}\text { Forward: TCAACGCAGGACCTAAAGACAT } \\
\text { Reverse: GCAGATAGCCAAGTTCAGGATG }\end{array}$ & $162 \mathrm{bp}$ \\
\hline TNF- $\alpha$ & NM204267 & $\begin{array}{l}\text { Forward: GCCCTTCCTGTAACCAGATG } \\
\text { Reverse: ACACGACAGCCAAGTCAACG }\end{array}$ & $71 \mathrm{bp}$ \\
\hline PTGES & NM001194983 & $\begin{array}{l}\text { Forward: GTTCCTGTCATTCGCCTTCTAC } \\
\text { Reverse: CGCATCCTCTGGGTTAGCA }\end{array}$ & $115 \mathrm{bp}$ \\
\hline $\mathrm{COX}-2$ & NM001167718 & $\begin{array}{l}\text { Forward: TGTCCTTTCACTGCTTTCCAT } \\
\text { Reverse: TTCCATTGCTGTGTTTGAGGT }\end{array}$ & $84 \mathrm{bp}$ \\
\hline iNOS & NM204961 & $\begin{array}{l}\text { Forward: CCTGGAGGTCCTGGAAGAGT } \\
\text { Reverse:CCTGGGTTTCAGAAGTGGC }\end{array}$ & $82 \mathrm{bp}$ \\
\hline IL-6 & NM204628 & $\begin{array}{l}\text { Forward:AAATCCCTCCTCGCCAATCT } \\
\text { Reverse:CCCTCACGGTCTTCTCCATAAA }\end{array}$ & $106 \mathrm{bp}$ \\
\hline IL-8 & NM205498 & $\begin{array}{l}\text { Forward:GGCTTGCTAGGGGAAATGA } \\
\text { Reverse:AGCTGACTCTGACTAGGAAACTGT }\end{array}$ & $199 \mathrm{bp}$ \\
\hline IL-1 $\beta$ & NM204524 & $\begin{array}{l}\text { Forward: CAGCAGCCTCAGCGAAGAG } \\
\text { Reverse:CTGTGGTGTGCTCAGAATCCA }\end{array}$ & $86 \mathrm{bp}$ \\
\hline IFN- $\gamma$ & GQ246226 & $\begin{array}{l}\text { Forward: GTGAAGAAGGTGAAAGATATCATGGA } \\
\text { Reverse:GCTTTGCGCTGGATTCTCA }\end{array}$ & $71 \mathrm{bp}$ \\
\hline $\mathrm{p} 53$ & NM205264.1 & $\begin{array}{l}\text { Forward: GAGATGCTGAAGGAGATCAATGAG } \\
\text { Reverse: GTGGTCAGTCCGAGCCTTTT }\end{array}$ & $145 \mathrm{bp}$ \\
\hline Bcl-2 & Z11961.1 & $\begin{array}{l}\text { Forward: ATCGTCGCCTTCTTCGAGTT } \\
\text { Reverse: ATCCCATCCTCCGTTGTCCT }\end{array}$ & $150 \mathrm{bp}$ \\
\hline Bax & XM001235092.3 & $\begin{array}{l}\text { Forward: GTGGTCAGTCCGAGCCTTTT } \\
\text { Reverse: TCCATTCAGGTTCTCTTGACC }\end{array}$ & $119 \mathrm{bp}$ \\
\hline Caspase-9 & XM424580.5 & $\begin{array}{l}\text { Forward: ATTCCTTTCCAGGCTCCATC } \\
\text { Reverse: CACTCACCTTGTCCCTCCAG }\end{array}$ & $130 \mathrm{bp}$ \\
\hline Caspase-3 & NM204725 & $\begin{array}{l}\text { Forward: CATCTGCATCCGTGCCTGA } \\
\text { Reverse: CTCTCGGCTGTGGTGGTGAA }\end{array}$ & $104 \mathrm{bp}$ \\
\hline Fas & XM421659 & $\begin{array}{l}\text { Forward: GCACTCGGTTTGGAGGTTGT } \\
\text { Reverse: CGTGGCATTCCTGCTTCTT }\end{array}$ & $197 \mathrm{bp}$ \\
\hline Caspase- 8 & NM204592 & $\begin{array}{l}\text { Forward: GGAAGCGGGAAGATATTGAG } \\
\text { Reverse: GCCCAGGTAGGAAGCTAGAA }\end{array}$ & $143 \mathrm{bp}$ \\
\hline GAPDH & K01458 & $\begin{array}{l}\text { Forward: AGAACATCATCCCAGCGT } \\
\text { Reverse: AGCCTTCACTACCCTCTTG }\end{array}$ & $182 \mathrm{bp}$ \\
\hline
\end{tabular}

levels were normalized by GAPDH. The dilution ( $\mathrm{v} / \mathrm{v})$ of primary chicken antibody: GAPDH, p53, Bcl-2, Bax, caspase- 9 and caspase- 3 were 1:1,000. Antibody against target protein was obtained from Wanleibio, China. And the dilution $(\mathrm{v} / \mathrm{v})$ of the secondary antibody was 1:7,500. The densitometry analysis of each blot was performed by employing Image J software, NIH, USA.

\section{Statistical analysis}

Statistical analyses of all data were performed using SPSS for Windows software (version 13; SPSS Inc., Chicago, IL, USA). Differences between the mean values of normally distributed data were assessed with a one-way ANOVA (Dunnett's $t$-test) and two-tailed Student's $t$-test. 
$P$-values of 0.05 or less were considered to be statistically significant. Differences between means were assessed using Tukey's honestly significant difference test for post hoc multiple comparisons. All values were expressed as the means $\pm \mathrm{SD}$ (standard error of means).

\section{Abbreviations}

$\mathrm{As}_{2} \mathrm{O}_{3}$, arsenic trioxide; BW, body weight; NF$\kappa \mathrm{B}$, Nucleic factor $\kappa \mathrm{B}$; ROS, reactive oxygen species; GSH, glutathione; GSH-Px, glutathione peroxidase; MDA, malondialdehyde; SOD, superoxide dismutase; CAT, catalase; TNF- $\alpha$, tumor necrosis factor- $\alpha$; PTGEs, prostaglandin E synthase; COX-2, cyclooxygenase-2; iNOS, inducible nitric oxide synthase; IL, interleukin; BF, bursa of Fabricius; IFN- $\gamma$, interferon- $\gamma$; FasL, Fas ligand; FADD, Fas-associated death domain.

\section{Authors' contributions}

Mingwei Xing and Zhijun Hou conceived and designed the experiments. Hongjing Zhao, Ying He, Siwen Li, Xiao Sun, Yu Wang and Yizhi Shao performed the experiments. Hongjing Zhao and Ying He analyzed the data and wrote the paper. Mingwei Xing and Zhijun Hou assisted in critically revising the manuscript.

\section{ACKNOWLEDGMENTS}

We would gratefully like to thank our staff, field workers and participants in China. We are especially grateful to Laura Pulscher for the correction of language.

\section{CONFLICTS OF INTEREST}

The authors declare no conflicts of interest. The founding sponsors had no role in the design of the study; in the collection, analyses, or interpretation of data; in the writing of the manuscript, and in the decision to publish the results.

\section{FUNDING}

This study was supported by the National Natural Science Foundation of China (Grant No.31672619); the Fundamental Research Funds for the Central Universities (Grant No. 2572016EAJ5) and the Natural Science Foundation of Heilongjiang Province (Grant No. C2015061).

\section{REFERENCES}

1. Khairul I, Wang QQ, Jiang YH, Wang C, Naranmandura H. Metabolism, toxicity and anticancer activities of arsenic compounds. Oncotarget. 2017; 8:23905-23926. doi: 10.18632 /oncotarget. 14733 .
2. Oberoi S, Barchowsky A, Wu F. The global burden of disease for skin, lung, and bladder cancer caused by arsenic in food. Cancer Epidemiol Biomarkers Prev. 2014; 23:1187-1194.

3. Gonzalez-Horta C, Ballinas-Casarrubias L, SanchezRamirez B, Ishida MC, Barrera-Hernandez A, GutierrezTorres D, Zacarias OL, Saunders RJ, Drobna Z, Mendez MA, Garcia-Vargas G, Loomis D, Styblo M, et al. A concurrent exposure to arsenic and fluoride from drinking water in Chihuahua, Mexico. Int J Environ Res Public Health. 2015; 12:4587-4601.

4. Pi K, Wang Y, Xie X, Su C, Ma T, Li J, Liu Y. Hydrogeochemistry of co-occurring geogenic arsenic, fluoride and iodine in groundwater at Datong Basin, northern China. J Hazard Mater. 2015; 300:652-661.

5. Gaworecki KM, Chapman RW, Neely MG, D’Amico AR, Bain LJ. Arsenic exposure to killifish during embryogenesis alters muscle development. Toxicol Sci. 2012; 125: 522-531.

6. Sumedha NC, Miltonprabu S. Diallyl trisulfide ameliorates arsenic-induced hepatotoxicity by abrogation of oxidative stress, inflammation, and apoptosis in rats. Hum Exp Toxicol. 2015; 34:506-525.

7. Li L, Liu Q, Fan L, Xiao W, Zhao L, Wang Y, Ye W, Lan F, Jia B, Feng H, Zhou C, Yue X, Xing G, et al. Protective effects of oxymatrine against arsenic trioxide-induced liver injury. Oncotarget. 2017; 8:12792-12799. doi: 10.18632/ oncotarget. 12478 .

8. Chen H, Lee LS, Li G, Tsao SW, Chiu JF. Upregulation of glycolysis and oxidative phosphorylation in benzo[alpha] pyrene and arsenic-induced rat lung epithelial transformed cells. Oncotarget. 2016; 7:40674-40689. doi: 10.18632/ oncotarget.9814.

9. Cheng PS, Weng SF, Chiang CH, Lai FJ. Relationship between arsenic-containing drinking water and skin cancers in the arseniasis endemic areas in Taiwan. J Dermatol. 2016; 43:181-186.

10. Flora SJ. Arsenic-induced oxidative stress and its reversibility. Free Radic Biol Med. 2011; 51:257-281.

11. Zhang K, Zhao P, Guo G, Guo Y, Tian L, Sun X, Li S, He Y, Sun Y, Chai H, Zhang W, Xing M. Arsenic Trioxide Attenuates NF-kappaB, Cytokine mRNA Levels in the Livers of Cocks. Biol Trace Elem Res. 2016; 170:432-437.

12. Zhao $\mathrm{P}$, Guo Y, Zhang W, Chai H, Xing H, Xing M. Neurotoxicity induced by arsenic in Gallus Gallus: Regulation of oxidative stress and heat shock protein response. Chemosphere. 2017; 166:238-245.

13. Guo Y, Zhao P, Guo G, Hu Z, Tian L, Zhang K, Sun Y, Zhang X, Zhang W, Xing M. Effects of Arsenic Trioxide Exposure on Heat Shock Protein Response in the Immune Organs of Chickens. Biol Trace Elem Res. 2016; 169:134-141.

14. Leonard SS, Harris GK, Shi X. Metal-induced oxidative stress and signal transduction. Free Radic Biol Med. 2004; 37:1921-1942. 
15. Ahmad S, Kitchin KT, Cullen WR. Arsenic species that cause release of iron from ferritin and generation of activated oxygen. Arch Biochem Biophys. 2000; 382:195-202.

16. Wang L, Wang Z, Liu J. Protective effect of N-acetylcysteine on experimental chronic lead nephrotoxicity in immature female rats. Hum Exp Toxicol. 2010; 29:581-591.

17. Wang L, Lin SQ, He YL, Liu G, Wang ZY. Protective effects of quercetin on cadmium-induced cytotoxicity in primary cultures of rat proximal tubular cells. Biomed Environ Sci. 2013; 26:258-267.

18. Wu B, Cui H, Peng X, Fang J, Zuo Z, Deng J, Huang J. Dietary nickel chloride induces oxidative stress, apoptosis and alters Bax/Bcl-2 and caspase- 3 mRNA expression in the cecal tonsil of broilers. Food Chem Toxicol. 2014; 63:18-29.

19. Yao HD, Wu Q, Zhang ZW, Zhang JL, Li S, Huang JQ, Ren FZ, Xu SW, Wang XL, Lei XG. Gene expression of endoplasmic reticulum resident selenoproteins correlates with apoptosis in various muscles of se-deficient chicks. J Nutr. 2013; 143:613-619.

20. Mughal MJ, Xi P, Yi Z, Jing F. Aflatoxin B1 invokes apoptosis via death receptor pathway in hepatocytes. Oncotarget. 2017; 8:8239-8249. doi: 10.18632/oncotarget.14158.

21. Chowdhury R, Chowdhury S, Roychoudhury P, Mandal C, Chaudhuri K. Arsenic induced apoptosis in malignant melanoma cells is enhanced by menadione through ROS generation, p38 signaling and p53 activation. Apoptosis. 2009; 14:108-123.

22. Yao HD, Wu Q, Zhang ZW, Li S, Wang XL, Lei XG, $\mathrm{Xu}$ SW. Selenoprotein W serves as an antioxidant in chicken myoblasts. Biochim Biophys Acta. 2013; 1830:3112-3120.

23. Li SW, Sun X, He Y, Guo Y, Zhao HJ, Hou ZJ, Xing MW. Assessment of arsenic trioxide in the heart of Gallus gallus: alterations of oxidative damage parameters, inflammatory cytokines, and cardiac enzymes. Environ Sci Pollut Res Int. 2017; 24:5781-5790.

24. Calatayud M, Gimeno-Alcaniz JV, Velez D, Devesa V. Trivalent arsenic species induce changes in expression and levels of proinflammatory cytokines in intestinal epithelial cells. Toxicol Lett. 2014; 224:40-46.

25. Gao H, Zhang X, Zheng Y, Peng L, Hou J, Meng H. S100A9-induced release of interleukin (IL)-6 and IL-8 through toll-like receptor 4 (TLR4) in human periodontal ligament cells. Mol Immunol. 2015; 67:223-232.

26. Lee KE, Kim EY, Kim CS, Choi JS, Bae EH, Ma SK, Kim KK, Lee JU, Kim SW. Macrophage-stimulating protein attenuates gentamicin-induced inflammation and apoptosis in human renal proximal tubular epithelial cells. Biochem Biophys Res Commun. 2013; 434: 527-533.

27. Yu HS, Liao WT, Chang KL, Yu CL, Chen GS. Arsenic induces tumor necrosis factor alpha release and tumor necrosis factor receptor 1 signaling in $\mathrm{T}$ helper cell apoptosis. J Invest Dermatol. 2002; 119:812-819.
28. Zhang C, Wang F, Zhang Y, Kang Y, Wang H, Si M, Su L, Xin X, Xue F, Hao F, Yu L, Xu J, Liu Y, et al. Celecoxib prevents pressure overload-induced cardiac hypertrophy and dysfunction by inhibiting inflammation, apoptosis and oxidative stress. J Cell Mol Med. 2016; 20:116-127.

29. Huang J, Cui H, Peng X, Fang J, Zuo Z, Deng J, Wang X, $\mathrm{Wu}$ B. Downregulation of TLR4 and $7 \mathrm{mRNA}$ expression levels in broiler's spleen caused by diets supplemented with nickel chloride. Biol Trace Elem Res. 2014; 158:353-358.

30. Tang K, Guo H, Deng J, Cui H, Peng X, Fang J, Zuo Z, Wang X, Wu B, Li J, Yin S. Inhibitive effects of nickel chloride $(\mathrm{NiCl})$ on thymocytes. Biol Trace Elem Res. 2015; 164:242-252.

31. Yin S, Cui H, Peng X, Fang J, Zuo Z, Deng J, Wang X, $\mathrm{Wu} \mathrm{B}$, Guo H. Toxic effect of $\mathrm{NiCl} 2$ on development of the bursa of Fabricius in broiler chickens. Oncotarget. 2016; 7:125-139. doi: 10.18632/oncotarget.6591.

32. Liu XF, Li ZP, Tie F, Liu N, Zhang ZW, Xu SW. Effects of manganese-toxicity on immune-related organs of cocks. Chemosphere. 2013; 90:2085-2100.

33. Cui H, Jing F, Xi P. Pathology of the thymus, spleen and bursa of Fabricius in zinc-deficient ducklings. Avian Pathol. 2003; 32:259-264.

34. Gul KT, Qadir SA, Imran AH, Ali SN, Balal AM. Hazardous impact of organic arsenical compounds in chicken feed on different tissues of broiler chicken and manure. Ecotoxicol Environ Saf. 2013; 87:120-123.

35. Moro AM, Charao M, Brucker N, Bulcao R, Freitas F, Guerreiro G, Baierle M, Nascimento S, Waechter F, Hirakata V, Linden R, Thiesen FV, Garcia SC. Effects of low-level exposure to xenobiotics present in paints on oxidative stress in workers. Sci Total Environ. 2010; 408:4461-4467.

36. Al-Harbi NO, Nadeem A, Al-Harbi MM, Ansari MA, AlSharari SD, Bahashwan SA, Attia SM, Al-Hosaini KA, Al HA, Ahmad SF. Airway oxidative stress causes vascular and hepatic inflammation via upregulation of IL-17A in a murine model of allergic asthma. Int Immunopharmacol. 2016; 34:173-182.

37. Zhang W, Xue J, Ge M, Yu M, Liu L, Zhang Z. Resveratrol attenuates hepatotoxicity of rats exposed to arsenic trioxide. Food Chem Toxicol. 2013; 51:87-92.

38. Xing M, Zhao P, Guo G, Guo Y, Zhang K, Tian L, He Y, Chai $\mathrm{H}$, Zhang W. Inflammatory Factor Alterations in the Gastrointestinal Tract of Cocks Overexposed to Arsenic Trioxide. Biol Trace Elem Res. 2015; 167:288-299.

39. Liu G, Wang ZK, Wang ZY, Yang DB, Liu ZP, Wang L. Mitochondrial permeability transition and its regulatory components are implicated in apoptosis of primary cultures of rat proximal tubular cells exposed to lead. Arch Toxicol. 2016; 90:1193-1209.

40. Walters J, Pop C, Scott FL, Drag M, Swartz P, Mattos C, Salvesen GS, Clark AC. A constitutively active and 
uninhibitable caspase-3 zymogen efficiently induces apoptosis. Biochem J. 2009; 424:335-345.

41. Yuan S, Wu B, Yu Z, Fang J, Liang N, Zhou M, Huang C, Peng $\mathrm{X}$. The mitochondrial and endoplasmic reticulum pathways involved in the apoptosis of bursa of Fabricius cells in broilers exposed to dietary aflatoxin B1. Oncotarget. 2016; 7:65295-65306. doi: 10.18632/oncotarget.11321.

42. Kim EM, Park JK, Hwang SG, Kim WJ, Liu ZG, Kang SW, Um HD. Nuclear and cytoplasmic p53 suppress cell invasion by inhibiting respiratory complex-I activity via Bcl-2 family proteins. Oncotarget. 2014; 5:8452-8465. doi: 10.18632/oncotarget.2320.

43. Kuo WW, Wu CH, Lee SD, Lin JA, Chu CY, Hwang JM, Ueng KC, Chang MH, Yeh YL, Wang CJ, Liu JY, Huang CY. Second-hand smoke-induced cardiac fibrosis is related to the Fas death receptor apoptotic pathway without mitochondria-dependent pathway involvement in rats. Environ Health Perspect. 2005; 113:1349-1353.

44. Hirsova P, Gores GJ. Death Receptor-Mediated Cell Death and Proinflammatory Signaling in Nonalcoholic Steatohepatitis. Cell Mol Gastroenterol Hepatol. 2015; $1: 17-27$.
45. Yang GF, Li XH, Zhao Z, Wang WB. Arsenic trioxide upregulates Fas expression in human osteosarcoma cells. Chin Med J (Engl). 2010; 123:1768-1773.

46. Karin M, Lin A. NF-kappaB at the crossroads of life and death. Nat Immunol. 2002; 3:221-227.

47. Poulaki V, Mitsiades CS, McMullan C, Fanourakis G, Negri J, Goudopoulou A, Halikias IX, Voutsinas G, TseleniBalafouta S, Miller JW, Mitsiades N. Human retinoblastoma cells are resistant to apoptosis induced by death receptors: role of caspase- 8 gene silencing. Invest Ophthalmol Vis Sci. 2005; 46:358-366.

48. Ghosh S, Karin M. Missing pieces in the NF-kappaB puzzle. Cell. 2002; 109:S81-S96.

49. Lynch DH, Ramsdell F, Alderson MR. Fas and FasL in the homeostatic regulation of immune responses. Immunol Today. 1995; 16:569-574.

50. Matzinger P. Tolerance, danger, and the extended family. Annu Rev Immunol. 1994; 12:991-1045.

51. Nutrient requirements of poultry. 9th rev. ed. Nutrient Requirements of Domestic Animals. 1994. 